36 A revised submission to:

37 Quaternary Science Reviews

${ }^{2}$ University of Pittsburgh, Department of Geology and Planetary Science, Pittsburgh, Pennsylvania, USA

${ }^{3}$ Canada Research Chair in Marine Geology, Institut des sciences de la mer de Rimouski (ISMER)\& GEOTOP, Rimouski, Québec, Canada

\title{
A 37,000-year Environmental Magnetic Record of Aeolian Dust Deposition from Burial Lake, Arctic Alaska
}

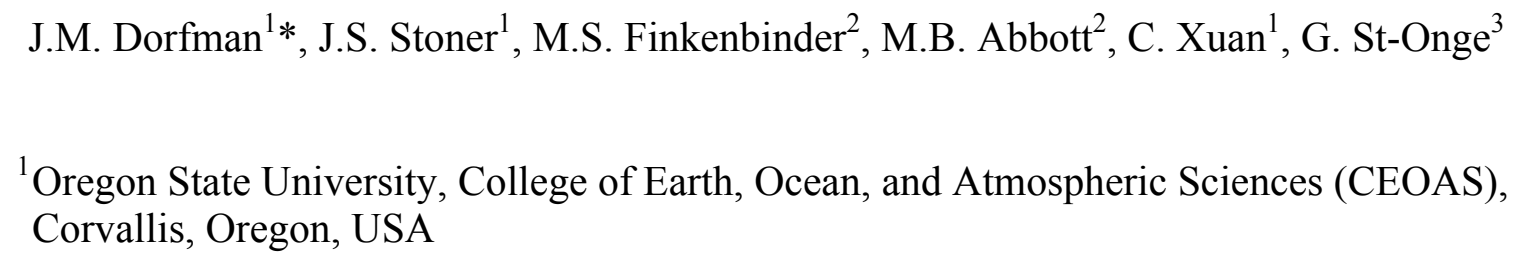

${ }^{1}$ Oregon State University, College of Earth, Ocean, and Atmospheric Sciences (CEOAS), Corvallis, Oregon, USA 


\subsection{Abstract}

Environmental magnetism and radiocarbon dating of Burial Lake

40 sedimentsconstrain the timing and magnitude of regional aeolian deposition for the

41 Noatak region of western Arctic Alaska for the last $\sim 37,000$ years. Burial Lake

$42\left(68.43^{\circ} \mathrm{N}, 159.17^{\circ} \mathrm{W}, 21.5 \mathrm{~m}\right.$ water depth) is optimally located to monitor regional dust

43 deposition because it is perched above local drainage and isolated from glacial

44 processes.Cores collected in the summer of 2010 were studied through the application of

45 magnetizations and progressive alternating field(AF) demagnetization of u-channel 46 samples, with additional data provided by computed tomography (CT) derived

47 density,hysteresis measurements, isothermal remanent magnetization (IRM)acquisition

48 experiments, organic carbon content, biogenic silica,physical grain size, radiocarbon

49 datingof terrestrial macrofossils, and point source magnetic susceptibility and X-ray

50 fluorescence(XRF) on split cores.With similar magnetic properties to regional

51 Alaskanloess deposits, low coercivity, highly magnetic material depositedduring the 52 glacial contrasts witha highcoercivity, weakly magneticcomponent found throughout the

53 record, consistent withlocally-derived detritus.The relative proportion of low coercivity

54 to high coercivity magnetic material, defined by the S-Ratios, is used to reconstruct the

55 regional input of dust to the basin over time. A four-fold decrease in the low coercivity

56 component through the deglacial transition is interpreted to reflect diminished dust input

57 to the region.Comparisons with potential sources of dust show that the timing of

58 deposition in Burial Lake is largely consistent with general aridity, lack of vegetative

59 cover, and increased windiness, rather than glacial advances or retreats. The influence

60 from subaerial exposure of continental shelves cannot be ruled out as a significant far-

61 field source of dust to interior Alaska during the Last Glacial Maximum (LGM), but is

62 unlikely to have been the sole source, or to have contributed to increased dust in both the

63 early and late Holocene.

64

65

\subsection{Introduction}

66

Aeolian dust has long been used as a proxy indicator for paleoclimateconditions

67 and atmospheric transport pathways (Rea, 1994). Much focus has been given to late-

68 Quaternary glacial-interglacial variations in "dustiness," with increased glacial dust flux 
attributed to colder temperatures, increased wind intensities, source aridity, limited vegetative cover, supply of glacier-derived silt, and broad exposure of continental shelvesfrom lowered sea level (Muhs et al., 2003a). Besides acting as an environmental tracer, aerosolic dust can also directly impact climate through radiative forcing (Tegen et al, 1996; Kohfeld and Harrison, 2001), or by fertilizing the world's oceans, thereby promoting phytoplankton blooms, which regulate atmospheric carbon dioxide (Hutchins and Brunland, 1998). At present however, the sources of dust and the forcing mechanisms responsible for its production, availability, transport, and deposition are poorly understood, thus limiting our ability to spatiallyreconstruct variations in dust flux, or usefully incorporate that information in general circulation models (GCMs).

In Alaska, the majority of dust-related paleoclimate data are derived from thick terrestrial loess deposits that accumulate along major river valleys and blanket large areas of the landscape (e.g.,Péwé, 1955). Determining the sources and depositional history of the Alaskan loess in relation to the timing of external environmental forcing mechanisms has been hindered by the often discontinuous and difficult to date nature of the deposits, as well as diagenetic processes that can alter the physical and chemical properties of these sediments (e.g., Liu et al., 1999). Lakes provide a low energy depositional setting, capable of producing continuous paleoclimate archives that may be less, or at least differently, influenced by the physical and chemical processes that hinder interpretation ofterrestrial loess deposits. Whileloess deposits are entirely composed of the material of interest, complicating any flux interpretations, lake sediments contain only an admixture that allows variations in dust,timing of specific events, and local environmental signalsto be assessed from the same archive.

We present a continuous $\sim 37,000$-year record of paleo-environmental change inferred from physical, geochemical, and environmental magnetic analyses of sediment cores from Burial Lake, Arctic Alaska, with a well-constrained radiocarbon chronology determined from accelerator mass spectrometry (AMS), that provides the oldest continuous lacustrine record from eastern Beringia to date.Previous magnetic studies on Alaskan loess (Begét, 1990; 2001; Begét et al., 1990; Vlag et al., 1999; Liu et al., 1999; Lagroix and Banerjee, 2002; Muhs et al., 2003a; Muhs and Budhan, 2006; Evans et al., 2011) provide diagnostic magnetic parameters that allow locally weathered hematite-rich 
100 bedrockto be distinguishedfrom ferrimagnetic (magnetite-rich) aeolian 101 dust.Performingthis study within a simple depositional basin with no direct inflow or 102 glacial influenceallows us to reconstruct the paleo-record of aeolian dust and its evolution 103 for NW Alaska.

\subsection{Regional Setting}

106 Burial Lake $\left(68.43^{\circ} \mathrm{N}, 159.17^{\circ} \mathrm{W}\right)$ lies at $460 \mathrm{~m}$ above sea level in the Northwest

107 Brooks Range, Alaska (Fig.1). It is a small $\left(\sim 0.8 \mathrm{~km}^{2}\right)$, roughly circular lake, with a 108 maximum depth of $21.5 \mathrm{~m}$. The small $\left(\sim 3.3 \mathrm{~km}^{2}\right)$ catchment, which is perched above the 109 surrounding tundra on a slight topographic high, has steep-sided embankments (3-5 m 110 high) that extend along most of the lake's perimeter. The lake has no direct inflow and 111 contains a small outlet stream on the southwest shoreline. Burial Lake is an oligotrophic, 112 hydrologically open system, and iswell mixed, with no evidence for year-round thermal 113 or chemical stratification (Abbott et al., 2010). During the mid and late Pleistocene, 114 mountain glaciers emanating from the Delong Mountains repeatedly dammed the Noatak 115 River forming a series of large proglacial lakes with surface areas as large as 4,400 $\mathrm{km}^{2}$ 116 (Hamilton, 2001) - collectively known as Glacial Lake Noatak(Hamilton and Van Etten, 117 1984). Glacial Lake Noatak appears not to have inundated Burial Lake since the Itkillik I 118 (early Wisconsinan) glacial advance (Hamilton, 2010), and the lake remained free of 119 glacial influence during the Last Glacial Maximum (LGM: 26.5 - 19 ka; Clark et al., 120 2009), lying just beyond the reach of mountain glaciers and Northern Hemisphere ice121 sheet extent (Hamilton, 2001).Based on its isolated geographic setting and lack of fluvial 122 input, we presume that sedimentation is influenced by aeolian deposition, with additional 123 inputs derived from seasonal runoff and biogenic accrual.

\section{$125 \quad 1.4$ Methods}

\section{1.4.1 Field Methods}

127 During the summer of 2010, three sediment cores ranging from 4.15 to $6.51 \mathrm{~m}$ in 128 length were collected; two from the deep central basin (A10 and C10: $21.5 \mathrm{~m}$ water 129 depth) and one nearer to the margin (D10: $8.5 \mathrm{~m}$ water depth) using a 2" diameter square130 rod Livingstone coring system designed to take $1 \mathrm{~m}$ successive drives. A larger, 2 5/8" 
131 polycarbonate barrel was used to recover the undisturbed sediment-water interface at

132 each location. Overlapping sections assured complete recovery in the upper part of each

133 record, but in order to achieve deeper core penetration, holes were cased with PVC pipe,

134 restricting the ability to overlap drives in the lower portions of the records.

135

136 1.4.2 Physical and Geochemical Analyses

137 Whole cores were split, described, and subsampled using ridged plastic u138 channels ( $2 \times 2 \mathrm{~cm}$ cross-sectional area) at the University of Pittsburgh. Organic content 139 and wet/dry bulk density were computed from standard loss on ignition (LOI) analysis, 140 weight percent biogenic silica (BSi) was determined, and X-ray fluorescence (XRF) 141 measurements provided major and minor elemental abundances (seeFinkenbinder et al., 142 this issuefor detailed methodology). At the Institut des sciences de la mer de Rimouski 143 (ISMER), in Rimouski (Quebec, Canada), u-channels were photographed using a high144 resolution digital camera mounted on a GEOTEK ${ }^{\mathrm{TM}}$ Multi Sensor Core Logger (MSCL). 145 Select samples were analyzed using smear-slides, and scanning electron microscope 146 (SEM) images were acquired to visualize grain-specific traits and characterize the 147 relative abundance of diatoms. Bulk physical grain size (including both lithogenic and 148 biogenic fractions) was measured at $10 \mathrm{~cm}$ increments using a Beckman-Coulter ${ }^{\mathrm{TM}} \mathrm{LS}$ 14913320 laser diffraction analyzer. Grain size distribution and statistical parameters were 150 calculated using Gradistat software (Blott and Pye, 2001). Computed Tomography (CT) 151 scans on theu-channels were obtained at the Institut national de la recherche scientifique, 152 Centre Eau-Terre-Environnement (INRS-ETE) in Quebec City, in order to visualize 153 sedimentary structures, assess possible core deformation, and aid stratigraphic 154 correlation.Following on methods provided by Duchesne et al. (2009) and Fortin et al., 155 (2013), the topograms (scans in the longitudinal plane) weretransferred into digital 156 DICOM format using a standard Hounsfield scale (HU scale) (Hounsfield, 1973) from1571024 to 3071 , where -1024 corresponds to the density of the air, 0 to the density of water, 158 and 2500 to the density of calcite.The MATLAB ${ }^{\mathrm{TM}}$ code developed at ISMER removes 159 effects of the plastic u-channel linerand air gaps from cracks in the sedimentto allow for a 160 more accurate $\mathrm{HU}$ calculation and a more realisticrepresentation of changes inrelative 161 density down-core. 
165 Point source low-field magnetic susceptibility $\left(k_{\mathrm{LF}}\right)$ was measured on split cores at 166 the University of Pittsburgh, at $2 \mathrm{~mm}$ intervals using a Bartington ${ }^{\mathrm{TM}} \mathrm{MS} 2$ meter and 167 MS2E1 sensor, mounted to a TAMISCAN-TS1 automatic stage conveyor. Rock 168 magnetic properties were studied through progressive alternating field (AF) 169 demagnetization of u-channel samples measured at $1 \mathrm{~cm}$ intervals using a $2 \mathrm{G}$ 170 Enterprises ${ }^{\mathrm{TM}}$ model 755-1.65UCsuperconducting rock magnetometerat the Oregon State 171 University Paleo- and Environmental Magnetism Laboratory. U-channel results were 172 processed using UPmag software (Xuan and Channell, 2009).

173 After natural remanent magnetization (NRM) measurements (the paleomagnetic 174 results of this study will be presented elsewhere), anhysteretic remanent magnetization

175 (ARM) was induced at a peak AF of $100 \mathrm{mT}$ with a $0.05 \mathrm{mT}$ direct current (DC) biasing 176 field and measured before and after AF demagnetizationup to a peak AF of 100 mTat 5 or $17710 \mathrm{mT}$ increments. An initial isothermal remanent magnetization(IRM) was imparted 178 with a DC field of 0.3 Tusing an impulse magnetizer designed for u-channel samples and 179 measured after demagnetization at the same steps as the ARM. A second IRMimparted 180 with a DC field of $1.0 \mathrm{~T}$ and considered to represent a saturation isothermal remanent 181 magnetization(SIRM) wasalso measured after demagnetization at the same steps as the 182 ARM. The response to these laboratory-applied magnetizations is not only a function of 183 the concentration of ferrimagnetic material within the sample, but also of the sample's 184 mineralogy and domain state (typically referred to as magnetic grain size).A variety of 185 ratios can be used to provide information on the magnetic assemblages' mineralogy and 186 grainsize. Commonly used ratios and their definitions have beentabulated in previous 187 studies (e.g.King and Channell, 1991; Stoner and St. Onge, 2007; Hatfield and Stoner, 188 2013). Here, we describe the ratios most important to this study.

189 Demagnetization ratios (e.g., $\mathrm{ARM}_{30} \mathrm{mT} / \mathrm{ARM}_{0} \mathrm{mT}, \operatorname{orSIRM}_{30} \mathrm{mT} / \mathrm{SIRM}_{0} \mathrm{mT}$ ) 190 provide information on the coercivity of the sample, which is a reflection of magnetic 191 grain size and/or mineralogy (Stoner and St-Onge, 2007). Higher values indicate higher 192 coercivity, or finer grainsize if the sample is of uniform ferrimagnetic mineralogy (Stoner 
193 and St-Onge, 2007). $\mathrm{ARM}_{0 \mathrm{mT}} / \mathrm{SIRM}_{0 \mathrm{mT}}$ is widely employed as a magnetic grain size 194 indicator for magnetite, with finer grain sizes yielding larger values (Evans and Heller, 195 2003). The parameter derived by normalizing the IRM at $0.3 \mathrm{~T}$ by the SIRM at $1.0 \mathrm{~T}$, 196 sometimes referred to as a pseudo S-Ratio (St-Onge et al., 2003) is analogous to the S197 ratio of Stober and Thompson (1979), and can be used to estimate the proportion of high 198 to low coercivity magnetic mineralogies (e.g., the proportion of magnetite to hematite). 199 Values closer to 1 denote an exclusively low coercivity ferrimagnetic mineral 200 assemblage, such as magnetite, while lower values signify the presence of higher 201 coercivity components, such as hematite (Thompson and Oldfield, 1986; King and 202 Channel, 1991; Stoner and St-Onge, 2007). The "hard" IRM (HIRM) is a measure of the 203 concentration of high coercivity material (e.g., hematite), and ishere defined as an 204 alternative optimized for u-channel measurements (Stoner and St-Onge, 2007): HIRM = $2050.5 *$ SIRM - IRM@0.3T).

206 Hysteresis experiments on subsampled bulk material were carried out at ISMER 207 on a Princeton Measurements Corporation ${ }^{\mathrm{TM}}$ MicroMagmodel 2900 alternating gradient 208 force magnetometer (AGM) to assess both mineralogy and magnetic grain size. 209 Hysteresis loops were corrected for paramagnetic/diamagnetic contributions, and the 210 following values were derived: the coercivity of magnetic minerals $(\mathrm{Hc})$, the coercivity of 211 remnance (Hcr), the saturation magnetization (Ms), and the saturation remnance (Mrs).

212 IRM acquisition experiments were performed on select bulk samples using a 213 Princeton Measurements Corporation $^{\mathrm{TM}}$ MicroMagmodel 3900vibrating sample 214 magnetometer (VSM) at Western Washington University. Data were smoothed using a 215 MATLAB $^{\mathrm{TM}}$ loess filter, and IRM decomposition was performed using IRMUNMIX 216 V2.2 (Heslop et al., 2002). Thermomagnetic analyses were attempted on four bulk 217 samples to study the temperature dependence of $k_{\mathrm{LF}}$, using an MS2WF Bartington ${ }^{\mathrm{TM}}$ 218 instrument. Measurements were heated at $2^{\circ} \mathrm{C}$ steps from room temperature $\left(24^{\circ} \mathrm{C}\right)$ up to $219700^{\circ} \mathrm{C}$, and subsequently cooled to room temperature. Unfortunately, given the weak $k_{\mathrm{LF}}$ 220 of Burial Lake sediments and the sample size limitations of the instrument,results were 221 inconclusive with values varying around zero andshowing no perceptible change with 222 temperature; therefore, these data are not presented. 


\section{1.4Age-Model and Composite Depth}

225 Down-core measurements and detailed core descriptions were used to

226 characterize lithologic subunits and transitions, and place the deep basin cores, A10 and

$227 \mathrm{C} 10$,on a common depth scale. The construction of the A10/C10 composite depth scale is

228 outlined in Figure 2. No stretching or squeezing of $\mathrm{C} 10$ drives was required to achieve a

229 satisfactory match. Given the quality, continuity, and extent of the A10 dataset, we focus

230 onour results from the $6.51 \mathrm{~m} \mathrm{~A} 10$ core. The A10/C10 composite depth scale (referred to

231 throughout as "depth") is utilized solely for the production of the age-depth model, in

232 which radiocarbon-dated samples were derived from both A10 and C10 cores(see Fig. 2).

233 AMS radiocarbon measurements were performed on 13 terrestrial macrofossil

234 samples from cores A10 and C10 at the Keck-Carbon Cycle AMS (KCCAMS) Facility at

235 the University of California, Irvine. Results are shown in Table 1 and Figure 3. Size-

236 dependent sample preparation backgrounds were subtracted based on measurements of

$237{ }^{14} \mathrm{C}$-free (Queets-A) wood. Radiocarbon ages were calibrated using Calib 6.0 (Stuiver et

238 al., 2005) and the IntCa109 calibration curve (Reimer et al. 2009).

239 Two out of the original 13 dates (UCIAMS \#109363 and \#89123; Table 1) were 240 excluded prior to generating the age-depth model (Fig.3). The first date at $359.5 \mathrm{~cm}$ 241 appears anomalously young given its stratigraphic position, and was possibly 242 contaminated by modern carbon during the combustion and graphitization of this very 243 small (0.017 mgC) sample (Oswald et al. 2005), which approaches the threshold limit for 244 AMS radiocarbon analysis at KCCAMS. Inclusion of this date would also invoke a 245 sudden and drastic increase in sedimentation rate (reaching $1.51 \mathrm{~m} / \mathrm{ka}$ ), which is 246 unsupported by additional radiocarbon constraints or lithologic evidence, andimprobable 247 giventhe depositional environment.The second date at $598 \mathrm{~cm}$ displays a slight age248 reversal with an adjacent date (\#89124; Table 1), though overlapping error bars suggest 249 both are statistically sound age-control points. We exclude date \#89123 based on its 250 slightly broader uncertainty and lower carbon yield.

251 The CLAM software for "classical" age-depth modeling (Blaauw, 2010) was used

252 to produce the "best fit" linearly interpolated age-model used in this paper (Fig. 3). The

253 CLAM analysis performed 1,000 age model iterations based on repeated sampling of the

254 calibrated age distributions for each radiocarbon sample to estimate the 'best fit' or 
255 weighted mean age for each depth. To further account for chronological uncertainty, we 256 apply a Monte Carlo-based approach that perturbs the interpolated age-depth model 257 10,000 times following a random draw from a normal distribution between the $2 \sigma$ 258 calibrated ${ }^{14} \mathrm{C}$ ages (Marcott et al., 2013). The uncertainty between the age control points 259 (Fig. 3) is modeled as a random walk, after Huybers and Wunch (2004), with 260 chronological uncertainty assumed to be auto-correlated through time and modeled as a 261 first order autoregressive (AR1) process.

\section{$263 \quad 1.6$ Results}

\section{1.6.1 Sedimentology and Lithostratigraphy}

265 The sediment record from Burial Lake continuously spans the last $\sim 37,000$ years, 266 with sedimentation rates (Fig. 3) ranging between 8.8 and $29.4 \mathrm{~cm} / \mathrm{ka}$, averaging 20.3 $267 \mathrm{~cm} / \mathrm{ka}$ for the whole record. The record shows distinct changes down-core from a 268 homogenous grayish brown (5YR 3/2) to dusky brown (5YR 2/2), argillaceous silt

269 sediment with higher organic carbon, low magnetic concentration, and high magnetic 270 coercivity at the top of the core, to a dark yellow brown $(10 \mathrm{YR} 4 / 2)$ to grayish brown 271 (5YR 3/2), fine to medium sandy argillaceous silt with minor proportion of coarse sand 272 and granules, lower organic carbon, higher magnetic concentration, and lowcoercivity 273 below. Based on these changes, the record can be divided into three distinct lithologic 274 subunits defined using down-core physical, geochemical, and magnetic properties (Fig.

275 4) that aid the paleo-environmental interpretation of the Burial Lake record.Wenote that 276 subunit boundariesdiffer slightly between this study and the paleoclimatic interpretation 277 of the Burial Lake sedimentary record presented by Finkenbinder et al.,this issue. 278 Despite our collaboration, this incongruence is to be expected given that both studies 279 make use of independent datasets and focuson related, but distinctly differentaspects and 280 mechanisms of regional environmental change. The inclusion of environmental magnetic 281 datasets in this study has particularly influenced our placement of lithologic 282 boundaries,providing an added dimension for interpreting lithologic changes down283 coreas they relate to sediment sourcing over time. 
Subunit 1 corresponds to the glacial period $(37.2-19.4 \mathrm{ka})$, and extends from the 287 base of the core $(651 \mathrm{~cm})$ to $285 \mathrm{~cm}$ (Fig. 4). Sediments consist mainly of pale 288 yellowish-brown (Munsell color: 10YR 6/2) to dark yellowish-brown (10YR 4/2) fine289 grained silts and clay and a small fraction of granules that exceeded the $2 \mathrm{~mm}$ 290 measurement limit of the laser diffraction analyzer, which was sieved and removed prior 291 to textural analysis. Mean physical grain size (Fig. 4) for Subunit 1 ranges between 4 and $29210 \mu \mathrm{m}$. Faint banding is observed in CT imagesfrom this interval, and throughout the 293 Burial Lake record (Fig. 4). CT density (324.4 $\pm 62.9 \mathrm{HU})$ and $k_{\mathrm{LF}}\left(1.3 \times 10^{-5} \pm 0.3 \times 10^{-}\right.$ $\left.294{ }^{5}\right)$ are relatively high and variable, while organic matter $(8.1 \% \pm 0.9 \%)$ and BSi $(1.4 \% \pm$ 295 0.4\%) contents are relatively low (Fig. 4). These data are consistent with smear-slides 296 and SEM images, which reveal sediment composed mainly of fine-grained lithogenic 297 detritus, and containing a near absence of diatoms. Though BSi in Subunit 1 (Fig. 298 4)shows no significant long-term trend, organic matter (Fig. 4) generally increases 299 downwards, while $k_{\mathrm{LF}}$ gradually decreases downwards. Other concentration-dependent 300 magnetic parameters, ARM, IRM, and SIRM (Fig. 4) mimic $k_{\mathrm{LF}}$, with relatively high and 301 variable intensities, consistent with higher concentrations of ferrimagnetic material in this 302 subunit. Ratios of $\mathrm{ARM}_{30 \mathrm{mT}} / \mathrm{ARM}_{0 \mathrm{mT}}$ and $\mathrm{SIRM}_{30 \mathrm{mT}} / \mathrm{SIRM}_{0 \mathrm{mT}}$ (Fig. 4; $0.49 \pm 0.03$, and $3030.38 \pm 0.04$, respectively) suggest sediments in Subunit 1 are dominated by a 304 lowcoercivity mineral assemblage, with values typical of magnetite. S-Ratios (Fig. 4) are 305 high $(0.93 \pm 0.02)$, increasing up coreto a maximum of $\sim 0.96$ near the top of Subunit 1 , 306 consistent with a high proportion of magnetite.Decreasing S-Ratios with depth (reaching $307 \sim 0.86$ at the base of the core) suggest an increasing proportion of highcoercivity minerals 308 (e.g. hematite) toward the bottom of the record.

309 While uncorrected hysteresis loops (Fig. 5) show high-field slopes indicative of 310 paramagnetic contributions, slope-corrected loops (Fig. 5) are consistent with 311 lowcoercivity ferrimagnetic contributions, with $\mathrm{Mrs} / \mathrm{Ms}$ values mostly ranging between 3120.1 and0.3, and saturation fields mostly below $0.2 \mathrm{~T}$ (Day et al., 1977; Tauxe, 1993). 313 Ratios of Mrs/Ms and $\mathrm{Hcr} / \mathrm{Hc}$ (Fig. 5)indicate that samples from Subunit 1 fall within the 314 pseudo single-domain (PSD) to just within the multi-domain (MD) fields for magnetite 315 (Day et al., 1977). 
316 Sub-centimeter scale, discrete peaks in magnetic parameters punctuate the record 317 at 582, 294, and $210 \mathrm{~cm}$ (33.1, 19.8, and $15.8 \mathrm{ka}$, respectively) (Fig. 4). These are 318 perhaps related to crypto-tephra deposits, though none of this relatively strongmagnetic 319 material could be isolatedand therefore, their source remains unknown.

320 Sedimentation rates (Fig. 3) in Burial Lake are elevated $(25.0-29.4 \mathrm{~cm} / \mathrm{ka})$ 321 throughout most of the glacial period, with the exception of the interval between 30.2 and $32235.6 \mathrm{ka}$, where they appear to drop to $9.6 \mathrm{~cm} / \mathrm{ka}$.Timing of sedimentation rate changes 323 and the magnitude of uncertainty are at least partially a function of the radiocarbon date 324 locations, and without a better-constrained chronology through the glacial interval, it is 325 difficult to address sedimentation rate in context with environmental change.

327 Lithologic Subunit $2(285-140 \mathrm{~cm})$

328 Subunit 2, corresponding to the deglacial transition $(19.4-9.8 \mathrm{ka})$, is 329 characterized by a transitional lithology extending between 285 and $140 \mathrm{~cm}$ (Fig. 4). 330 Lower sediments are dark yellowish-brown (10YR 4/2) in color, changing to a dusky331 brown (5YR $2 / 2)$ at $\sim 225 \mathrm{~cm}$, and eventually grading to greyish-brown (5YR 3/2) in the 332 upperpart of the transition. Marked declines in CT density, $k_{\mathrm{LF}}$, ARM, IRM, and SIRM 333 (Fig. 4) are accompanied by increased organic content and BSi (Fig. 4). Sediments are 334 still dominated by silts and clay, but mean physical grain size increases substantially, 335 peaking around $160 \mathrm{~cm}$ at $26 \mu \mathrm{m}$ (Fig. 4) with the addition of a fine to very fine sand 336 fraction and an increased proportion of coarse to very coarse silt. As physical grain size 337 samples were not pre-treated to remove biogenic components, the increase in grain size 338 during this time interval may be attributed to the increased abundance of diatoms, which 339 were often larger than lithic grains when observed through SEM imaging. Ratios of $340 \mathrm{ARM}_{30 \mathrm{mT}} / \mathrm{ARM}_{0 \mathrm{mT}}$ and $\mathrm{SIRM}_{30 \mathrm{mT}} / \mathrm{SIRM}_{0 \mathrm{mT}}$ (Fig. 4) increase through the transition, and 341 since coercivity variations within these parameters are mainly limited to what can be 342 achieved by AF demagnetization at low fields, the increase in coercivity is consistent 343 with a fining of magnetic grain size, rather than a change in mineralogy. This is 344 supported by increasing values of $\mathrm{ARM}_{0 \mathrm{mT}} / \mathrm{SIRM}_{0 \mathrm{mT}}$ (Fig. 4), as $\mathrm{ARM}$ is sensitive to 345 fine-grained magnetite (Evans and Heller, 2003).Bulk magnetic grainsize is contrary to 346 mean physical grain size (Fig. 4),however, the influence of biogenic contributions to bulk 
347 physical grain size as well as magnetic mineralogical changes on these ratios must be 348 considered.

349 A distinct change in S-Ratios is observed to occur around $212 \mathrm{~cm}$, (16 ka; Fig. 4).

350 This is interpreted to result from a change in magnetic mineralogy (Thompson and

351 Oldfield, 1986; King and Channel, 1991; Stoner and St. Onge, 2007). HIRMs (Fig. 4)

352 decrease through this interval,as do $k_{\mathrm{LF}}$, ARM, IRM, and SIRM, demonstrating the

353 overall decrease in concentration of both the high andlow coercivity magnetic

354 components. Because the decrease in concentration of both low and high coercivity

355 minerals is associated with increases in productivity indicators (Fig. 4), it results at least

356 partially from organic/biogenic dilution of the detrital components. S-Ratios, on the

357 other hand, are insensitive to organic/biogenic dilution, and sharply decline to $\sim 0.83$ (Fig.

358 4), reflectingan increase in the proportion of high coercivity minerals (hematite) relative

359 to low coercivity minerals (magnetite) through this transitional subunit. As discussed

360 above, magnetic grainsizes of the low coercivity component fine through the transition, a

361 pattern inconsistent with diagenetic dissolution. S-Ratios slightly increase for the

362 remainder of Subunit 2, but remain below 0.86. Sedimentation rates (Fig. 3) appear to

363 decrease through the deglacial transition, averaging $18.3 \mathrm{~cm} / \mathrm{ka}$, and reaching their lowest

364 overall values between 16.8 and $11.7 \mathrm{ka}$.

365

366 Lithologic Subunit $3(140-0 \mathrm{~cm})$

367 Subunit 3, dating to the Holocene (9.8 ka - present), extends from $140 \mathrm{~cm}$ to the

368 top of the core ( $0 \mathrm{~cm}$; Fig. 4$)$. Sediments consist mainly of fine to very coarse silt with

369 small contributions ofvery fine sand and clay - dusky-brown (5YR 2/2) at the base and

370 grading to greyish-brown (5YR 3/2). Uppermost sediments are dark-yellowish brown

371 (10YR 4/2). Mean physical grain size remains elevated (Fig. 4), ranging between 13 and

$37218 \mu \mathrm{m}$. A homogenous, fine-grained ferrimagnetic assemblage is suggested by higher

373 values of $A R M_{0 \mathrm{mT}} / \mathrm{SIRM}_{0 \mathrm{mT}}$, as well as $\mathrm{ARM}_{30 \mathrm{mT}} / \mathrm{ARM}_{0 \mathrm{mT}}$ and $\mathrm{SIRM}_{30 \mathrm{mT}} / \mathrm{SIRM}_{0 \mathrm{mT}}$

374 ratios, $(0.55 \pm 0.02$ and $0.62 \pm 0.03$, respectively; Fig. 4). CT density is low and less

375 variable $(-47.1 \pm 62.8 \mathrm{HU})$, along with $k_{\mathrm{LF}}\left(0.26 \times 10^{-5} \pm 0.07 \times 10^{-5}\right)$ and other

376 concentration dependent magnetic parameters (Fig. 4). Organic content peaks near the

377 boundary of Subunits 2 and 3 at 19.3\% (Fig. 4), then slightly decreases until $\sim 129 \mathrm{~cm}$, 
378 but remains elevated $(13.2 \% \pm 1.1 \%)$ compared to previous subunits. BSi is also 379 elevated $(11.4 \% \pm 2.4 \%)$, increasing steadily from the base of Subunit 3 before leveling 380 off in the upper $\sim 100 \mathrm{~cm}$ (Fig. 4). These data are consistent with smear-slides and SEM 381 images that reveal an increased abundance of diatoms and organic detritus, relative to 382 clastic mineral matter.Noisy hysteresis loops (Fig. 5) reflect the low ferrimagnetic 383 concentrations in Subunit 3, which approach instrument limitations and result in 384 somewhat scattered hysteresis results with respect to domain-state boundaries (Fig. 5).

385 S-Ratios $(0.81 \pm 0.02)$ decline abruptly again between 140 and $103 \mathrm{~cm}$, reaching 386 values as low as $\sim 0.78$ (Fig. 4). Values increase again in the upper $\sim 35 \mathrm{~cm}$, but do not 387 exceed 0.85. Smaller values of XRF Fe $/ k_{\mathrm{LF}}$ in Subunit 1 (Fig. 4) suggest the iron content 388 of these sediments is more or less accounted for by $k_{\mathrm{LF}}$, meaning that iron bearing 389 minerals contribute heavily towards the total magnetic susceptibility. Conversely, the higher ratios observed during Subunits 2 and 3 reflect sediments that are high in iron, yet

391 display weak values of $k_{\mathrm{LF}}$. This "unaccounted" iron could be tied up in minerals like 392 hematite, an iron oxide that is elevated in iron, but possesses a weaker $k_{\mathrm{LF}}$ (Dunlop and 393 Özdemir, 2001), consistent with the increased proportion of highcoercivity minerals. 394 While not a definitive indicator of magnetic mineralogy, XRF $\mathrm{Fe} / k_{\mathrm{LF}}$ 395 providescomplimentary geochemical evidence of a contrasting mineralogy between the 396 upper and lower subunits. Sedimentation rates are also comparatively low (11.6 - 16.7 $397 \mathrm{~cm} / \mathrm{ka}$ ) during the Holocene (Fig. 3), displaying a slight increasing trend from the early 398 Holocene to present.

\subsubsection{IRM Acquisition/Decomposition Results}

To further quantify the magnetic mineralogical changes, IRM acquisition curves 403 Representative normalized curves from each lithologic subunit are shown in Figure 6. 404 Results indicate similar coercivity distinctions as observed in the S-Ratios (Fig. 4), with 405 samples from Subunit 1 acquiring magnetization more quickly than samples from 406 Subunits 2 and 3, anddisplaying lowcoercivity behavior characteristic of ferromagnetic 407 minerals (e.g., magnetite). All samples reach magnetic saturation within a narrow 408 range of field intensities (1200-1400 mT), with samples from Subunits 2 and 3 
409 saturating towards the high end of this range, indicating the presence of a high 410 coercivity mineral assemblage (e.g. hematite). Regardless of the exact mineralogy,

411 S-ratios and the following IRM decomposition results show it to be fundamentally 412 distinct from the magnetite-rich sediments in Subunit 1.

413 IRM decomposition enables the separation of remanence-bearing sediments into 414 their individual component contributions, allowing us to estimate the number of 415 endmembers needed to explain the bulk magnetic properties of the sediments, and track 416 relative changes in endmember contributions over time (depth). IRM decomposition 417 results (Fig. 7) are based on smoothed input curves from Figure 6, with results for all 418 samples provided in Table 2. Smoothing was required because the extremely weak 419 magnetization of these samples resulted in measurement noise. The consistency of 420 results supports the interpretations. Burial Lake sediments are best described by a two421 component model, with both lowcoercivity (component 1) and highcoercivity 422 (component 2) sources present throughout the record. The $\mathrm{R}^{2}$ correlation of smoothed 423 input data to the sum of one, two, three, and four components, are provided in Appendix 424 A, supporting our use of a two-component model. Following on the principle of 425 parsimony (Imbrie, 1963), which was specifically envisioned for the case of un-mixing 426 models, this provides the best-fitting, simplest, and most geologically meaningful 427 solution.

428 Excluding two samples, which contained either excessive measurement noise 429 (sample B), or a third lowcoercivity component (sample G), mean coercivities for 430 component 1 (Table 2 ) are extremely consistent $(44.0 \pm 2.7 \mathrm{mT})$, suggestive of a common 431 lowcoercivity mineralogy, and consistent with a fine-grained, PSD magnetite source. 432 Mean coercivities for component 2 (Table 2; $270.2 \pm 56.8 \mathrm{mT}$ ) are much higher, with 433 increased variability perhaps indicating variable highcoercivity sources, oran artifact 434 induced by smoothing in the much noisier highcoercivity range (Fig. 7).

435 Relative percent contributions depicted in Figure 7 and Table 2 illuminate 436 coercivity trends observed in S-Ratios (Fig. 4).Though highcoercivity mineralsare present 437 throughout the record, their influence on S-Ratiosis at times overshadowed by increased 438 abundance ofa lowcoercivity,ferrimagnetic mineralogy (e.g., magnetite), an observation 439 consistent with previous studies on S-Ratio sensitivity (e.g., Frank and Nowaczyk, 2008) 
440 that conclude an overwhelming percentage of hematite is needed to cause any major 441 decrease in S-Ratios. Sample H $(474 \mathrm{~cm})$ from Subunit 1 provides an instructive 442 example, containing an overwhelming 93.0\% component 1 (compared with $7.0 \%$ 443 component 2), corresponding to a high S-Ratio of 0.94 . Only when component 1 444 contributions are reduced throughout Subunits 2 (e.g., sample E, $190 \mathrm{~cm}: 87.8 \%$ ) and 3

445 (e.g., sample A, $40 \mathrm{~cm}$ : 68.2\%), can component 2 drive S-Ratios towards lower values 446 ( 0.85 and 0.78 , respectively). The overall $\sim 25 \%$ reduction in component 1 that occurs 447 between samples $\mathrm{H}$ at $474 \mathrm{~cm}$ and sample $\mathrm{A}$ at $40 \mathrm{~cm}$ is consistent with the general 448 decline in S-Ratios that occurs throughout Subunits 2 and 3. A 12.4\% increase in 449 component 1 is also observed to occur between samples I $(574 \mathrm{~cm})$ and $\mathrm{H}(474 \mathrm{~cm})$, in 450 keeping with increasing S-Ratios from the base of the core. Though components 1 and 2 451 refer specifically to IRM acquisition/decomposition results from a few discrete 452 measurements, they are representative of the low and highcoercivity mineralogies present 453 in variable proportion throughout the Burial Lake record, identified through the number 454 of different rock-magnetic observations pertaining to coercivity/mineralogy that are 455 measured more continuously throughout each subunit (Fig. 4).

\section{$457 \quad 1.7$ Discussion}

458 1.7.1 Lithologic Interpretation

459 Down-core physical, geochemical, and magnetic parameters are shown versus age 460 in Figure 8, allowing us to place our paleo-environmental results in the context of time. 461 The pattern of variability observed in the Burial Lake record, with high concentrations of 462 low coercivity magnetic minerals and a low proportion of high coercivity minerals in the 463 lower part of the record, transitioning to reduced concentrations of low coercivity 464 mineralsand an increased proportion of high coercivity minerals at the top of the record, 465 could be explained by diagenetic alteration through post-depositional magnetite 466 dissolution (e.g., Snowball, 1993), a change in sediment source(s)(e.g., Thompson and 467 Oldfield, 1986), or some combination of both. Although negative correlations between 468 organic carbon and magnetic concentration are consistent with diagenetic alteration, they 469 are also consistent with the general climatic transition from glacial to interglacial 470 conditions. As Burial Lake isoligotrophic, hydraulically open, and is welloxygenated 
471 with no evidence for significant stratification, itfits phase 1 conditions of Evans and 472 Heller (2003), suggesting sediments are unlikely to haveundergone significant magnetic 473 dissolution. Additionally, there is little physical evidence (e.g., laminations, gas 474 production, hydrogen sulfide smell, significant color changes, or pyrite formation) at any 475 point in the record to suggest significant reducing and/or sulfidic conditions generally 476 associated with magnetic dissolution (e.g., Karlin and Levi, 1983; Canfield and Berner, 477 1987; Anderson and Rippey, 1988; Rowan et al., 2009).X-Ray diffraction (XRD) 478 resultsfrom Finkenbinder et al., (this issue) also show no indication of pyrite 479 formation. There is no progressive decrease in intensity and/or corresponding increase in 480 ferrimagnetic grain-size with depthin Subunit 3 (Fig. 4), as would be expected for 481 magnetic dissolution (Karlin and Levi, 1983;Anderson and Rippey, 1988; Snowball 482 1993). The ferrimagnetic grainsize in Subunit 3 is finer than that observed deeper in 483 the core, also inconsistent with magnetic dissolutionof a similar parent material (Karlin 484 and Levi, 1983; Anderson and Rippey, 1988; Snowball, 1993).

485 On the basis of these observations, the rock magnetic variability and distinct shift 486 in mineralogy observed in the Burial Lake record is more likely derived from variations 487 in sediment sources, which we suspect reflect local versus far-field (aeolian) material.We 488 interpret the lowcoercivity ferrimagnetic (e.g., magnetite) component to reflect the input 489 of aeolian dust based on the following cumulative reasoning:

490 1. A lowcoercivity magnetic mineralogy dominates glacial period sedimentation in 491 Burial Lake, (i.e., Subunit 1; Fig. 8), and enhanced glacial-age loess production is 492 well supported, with ubiquitous deposits found throughout Alaska (Péwé, 1955; Muhs 493 et al., 2003a; 2003b).

494 2. Glacial-age sediments from Burial Lake have comparable magnetic characteristics to 495 Alaskan loess (Fig. 5-8; Table 2), which contains significant quantities of magnetite, 496 contributing to high values of $k_{\mathrm{LF}}$, and coercivity similar to that of component 1 (Fig. 497 7) (Begét, 1990; 2001; Begét et al., 1990; Vlag et al., 1999; Liu et al., 1999; Lagroix 498 and Banerjee, 2002; Muhs et al., 2003a; Muhs and Budhan, 2006; Evans et al., 2011).

499 3. Sedimentation in Burial Lake during the glacial period is characterized by extensive 500 fine-grained deposition of silts and clays with a mean physical grain size of $4-10$ 
$\mu \mathrm{m}$ (Fig. 8). This is within the lower grain size range of the Alaskan loess (Muhs and Buhdan, 2006), and consistent with aeolian deposition.

503 4. Detrital flux $\left(\mathrm{F}_{\text {detrital }}=\mathrm{SR} *[\mathrm{BD} *(100 \%-\% \mathrm{OM}-\% \mathrm{BSi})]\right)$, calculatedby removing

504 weight percent organic matter (OM) and biogenic silica (BSi) contributions from total 505 dry bulk density (BD), and factoring in sedimentation rate (SR), shows that 506 mineralogenic input was approximately four and half times greater during the glacial 507 period than in the Holocene, consistent with the gradual diminished relative 508 contribution of lowcoercivity ferrimagnetic components and the decrease in S-Ratios 509 through the deglacial transition (Fig. 7, 8).

510 5. Based on its regional geographic setting, Burial Lake appears sensitive to aeolian 511 deposition. Given its relatively small watershed and lack of inflowing streams, the 512 only means to achieve increased detrital flux during the glacial period (other than 513 increasing dust flux) would be to increase precipitation and spring runoff. This 514 conflicts with widespread evidence for prevailing xeric conditions over the glacial515 age landscape of interior Alaska (Hopkins, 1982; Abbott et al., 2000; Finkenbinder et 516 al., 2014).

517 6. Sedimentation rates are comparatively low during the Holocene (Fig. 3), and the 518 concentration of the lowcoercivity magnetic component is diminished (Fig. 519 7),although it still accounts for the bulk of the magnetization in Holocene sediments. 520 Again, based on regional geography, Burial Lake likely still remains sensitive to 521 aeolian deposition. While less extensive and episodic in nature, Alaskan loess 522 deposition continued even after the LGM, with deposits as recent as $\sim 3,000{ }^{14} \mathrm{C}$ yr 523 BPfound at Delta Junction, south of Fairbanks (Muhs et al., 2003a). Modern dust 524 storms are common in Alaska during the snow-free months of spring, summer, and 525 early fall (Begét, 2001). In some areas, river bars exposed to wind in winter can 526 cause dust to accumulate in winter snowpack before melting out in the spring (Péwé, 527 1955).

528

529 For the following cumulative reasoning, highcoercivity material is interpreted as a 530 locally-derived source, weathered from surrounding uplands and transported to Burial 531 Lake during seasonal runoff events: 
532 1. Though variable, highcoercivity material is present throughout all parts of the Burial 533 Lake record (Fig. 7, Table 2), and requires an activesediment source irrespective of 534 the drastic environmental changes associated with the glacial-interglacial transition, 535 and therefore, must be immediately available from the local catchment.

536 2. The Brooks Range, while geologically diverse, has been shown to contain significant 537 highcoercivity mineral concentrations within the Paleozoic and Mesozoic 538 sedimentary and metasedimentary strata that comprise regional bedrock topography 539 (Slack et al., 2004; Mayfield et al., 1984; Ellersieck et al., 1984). Among such 540 deposits are large outcroppings of the Kayak shale (early Mississippian), the same 541 friable and highly oxidized (i.e., hematite bearing) material responsible for the 542 reddish hue in sediments from Blue Lake (Bird et al., 2009) in the central Brooks 543 Range near Atigun Pass.

545 Given these deductions, we suggest that S-Ratios, though only a measure of 546 relative proportion, are a sensitive indicator for dust input to Burial Lake, with higher 547 values indicating periods of increased accumulation, and lower values indicating periods 548 of diminished flux, while IRM acquisition/decomposition allows for background levels of 549 highcoercivity material to be discerned throughout the record.

550

551 1.7.2 Local and Far-field Sources of Dust, Timing of Deposition, and Potential Forcing 552 Mechanisms

553 There are three plausible ways in which aeolian dust could be made available for 554 transport to Burial Lake: 1) Sea level lowering could expose large portions of the 555 continental shelves, providing a potential far-field source of dust to Burial Lake; 2) 556 Expansion of alpine glaciers in the Brooks Range or elsewhere could also generate a 557 potential local revenue of dust (though it would need to be weathered from localized 558 lowcoercivity bedrock to fit our description of component 1); and 3) A dry and windy 559 environment with little vegetative cover could expose the landscape to deflation, 560 generating a widespread source of dust without the need to invoke sea level or glacial 561 activity. In the remainder of this study, we provide a paleo-environmental interpretation 562 of the Burial Lake record, devoting particular attention to the timing and extent of dust 
563 deposition as depicted by the S-Ratio proxy so as to distinguish the mechanism(s) 564 responsible for increased or decreased dust input to Burial Lake, and therefore identify or 565 exclude potential sources.

566

567 The Last Glacial Period(Subunit 1) 37.2 - $19.4 \mathrm{ka}$

568 S-Ratios are highest and magnetic concentrations are greatest during the last 569 glacial period (Fig. 8), and reflect a general increasing trend in dust accumulation from 570 moderate levels in the earliest portion of the record during Marine Isotope Stage 3 (MIS5713 ; i.e., prior to $\sim 30 \mathrm{ka})$, reaching a maximum at the height of the global LGM (19-20

572 ka). Fine-grained, lithogenic sediments with relatively high CT density and increasing 573 values of $k_{\mathrm{LF}}$ (Fig. 8) are consistent with increasing accumulation of aeolian dust. Low 574 organic matter (Fig. 8) and the general absence of terrestrial macrofossils for AMS 575 radiocarbon analysis between $\sim 30$ and $\sim 17$ ka (Fig. 3), suggest the surrounding landscape 576 was largely devoid of substantial vegetation, indicating a windswept tundra environment 577 that was colder and drier than present. Low BSi (Fig. 8) suggests diminished lake 578 productivity due to cold conditions with a short, ice-free summer season, along with 579 potentially turbid and/or nutrient depleted waters. Abbott et al. (2010) determined that a 580 depositional hiatus in the shallower portions of Burial Lake occurred between 33.0 and $58124.3 \mathrm{ka}$ (ages recalibrated using Calib 6.0 and the IntCAL09 calibration curve; 582 Finkenbinder et al., this issue), corresponding to a significant drop in lake level from 583 decreased moisture availability.

584 Proxy data from Burial Lake are consistent with evidence elsewhere in the region 585 depicting extremely cold, arid, and windy conditions leading up to the LGM (Hopkins, 586 1982;Muhs et al., 2003a; Abbott et al., 2000; Kurek et al., 2009; Abbott et al., 2010; 587 Finkenbinder et al., 2014), highlighting the potential for significant landscape deflation 588 and production of dust. Though loess production and windiness appear to increase, Muhs 589 et al., (2003a) note surprisingly little accumulation of loess during the LGM, which they 590 attribute to sparse vegetation and limited ground surface roughness. Though these 591 attributes may inhibit terrestrial loess accretion, they would not necessarily prohibit 592 deposition in lakes. Burial Lake S-Ratios may therefore offer a more accurate portrayal of 
593 dust production during the LGM, further demonstrating the advantages lacustrine records 594 hold over traditional terrestrial loess deposits.

595 Bracketing radiocarbon ages of 30 and $13 \mathrm{ka}$ in the central (Hamilton, 1982) and 596 western (Hamilton 2001) Brooks Range, constrain the timing of the subsequent Itkillik II 597 (late Wisconsinan) glaciation, which reached its maximum extent between 27 and $25 \mathrm{ka}$ 598 (Fig.9; Briner and Kaufman, 2008). Though extensive in the eastern and central parts of 599 the Brooks Range, growth of alpine glaciers (and the potential for dust generation) 600 became progressively more restricted towards the west, primarily due to the lower-lying 601 topography of mountain valleys(Hamilton and Labay, 2011). Therefore, many alpine 602 valleys in the western Brooks Range did not support glaciers of Itkillik II age (Hamilton 603 and Labay, 2011). This, combined with the fact that S-Ratios do not diminish in response 604 to waning Brooks Range glaciers from their maximum Itkillik II extents (they in fact 605 continue to increase; Fig.9), suggests that local glaciers likely did not contribute 606 substantially to the supply of dust deposited in Burial Lake during the glacial period, or at 607 least cannot be held accountable for the increasing trend in in S-Ratios leading up to the 608 LGM (Fig. 9).

609 Increased exposure of Beringian continental shelves from rapidly declining sea 610 level may help to explain the increase in dust input over the glacial period, particularly 611 considering that newly exposed coastline would likely have lacked substantial vegetative 612 cover and been subjected to the same arid and windy conditions that persisted in the 613 continental interior. A marine source has been inferred for glacial-age loess found in 614 coastal locations along the Seward Peninsula, in USGS marine sediment cores from 615 Norton Sound, and in Zagoskin Lake on St. Michael's Island (Muhs et al., 2003b). While 616 these sites are limited to the western coast of Alaska, it is not unreasonable to think that 617 winds could transport such material further inland. If continental shelves are viable 618 sources of far-field dust, the surface area over which dust could be generated is massive 619 in comparison to the relatively small footprint of mountain glaciers.

620 In comparing Burial Lake S-Ratios to relative sea level (Fig.9; Clark et al., 2009) 621 we observe only a moderate amount of dust accumulation occurring in the earliest part of 622 the record, during MIS-3, in keeping with somewhat elevated sea level (roughly $70 \mathrm{~m}$ 623 below present). As sea level declined, subaerial extent of continental shelves increased 
624 until sea level reached its lowest position $(-123 \mathrm{~m})$ at approximately $21 \mathrm{ka}$ (maximum 625 low-stand shelf exposure is depicted in Figure10). S-Ratios respond accordingly, 626 reflecting an increase in dust input to Burial Lake.

628 The Deglacial Transition (Subunit 2) $19.4-9.8 \mathrm{ka}$

629 The lithologic transition, here characterized by decreasing magnetic concentration 630 and CT density, accompanied by rising organic content and BSi (Fig. 8), is commonly 631 observed in sediment records that span the glacial/interglacial transition. The beginning 632 of the transition $(19.4 \mathrm{ka})$ is coincident with the onset of Northern Hemisphere 633 deglaciation (Clark et al., 2009; 2012). At Burial Lake, rising lake levels between 20.0 634 and $19.0 \mathrm{ka}$ indicate increasing effective moisture (Abbott et al., 2010), while 635 choronomids indicate increasing summer temperatures by $17.0 \mathrm{ka}$ (Kurek et al., 636 2009),consistent with the observed rise in aquatic productivity, as evidenced by organic 637 content and BSi (Fig. 8).Concentration dependent magnetic parameters decrease (Fig. 8), 638 partially in response to organic/biogenic dilution of lithogenic sediments. However, 639 dwindling sedimentation rates (Fig. 3) imply a decline in detrital flux as well, which S640 Ratios (Fig. 8) suggest is in large part due to a reduction in low coercivity aeolian dust 641 contribution. As many of the harsh conditions, once favorable to landscape deflation and 642 production of dust during the glacial period, were ameliorated following the LGM, dust 643 sources were effectively shut off from Burial Lake, permitting Holocene sedimentation to 644 be dominated by local highcoercivity input.

645 Although Burial Lake begins to respond to global climate changes at $\sim 19.4 \mathrm{ka}$ 646 (Finkenbinder et al., this issue), the major decrease in S-Ratios that commences by $\sim 16$ $647 \mathrm{ka}$, is broadly synchronous with the onset of the Bølling interstadial at $14.7 \mathrm{ka}$ 648 (Rasmussen et al., 2006), identified in $\delta^{18} \mathrm{O}$ temperature proxy records from Greenland 649 NGRIP ice cores (Fig.9; NGRIP project members, 2004), and in tune with rising summer 650 insolation (Fig.9; Berger and Loutre, 1991). This is consistent with regional proxy data 651 that reflect a local expression of Bølling warming and a rapid climatic teleconnection 652 between the North Atlantic and North Pacific sectors (Broeker, 1994; Mikolajwicz et al., 653 1997; Hostetler et al., 1999; Davies et al., 2011; Praetorius and Mix, 2014). A rapid 18 $654 \mathrm{~m}$ rise in water levels at Birch Lake, south of Fairbanks at $\sim 15 \mathrm{ka}$ (Fig. 9; Abbott et al., 
6552000 ) and rising and higher lake levels at nearby Harding Lake by $\sim 14$ ka (Finkenbinder 656 et al., 2014) indicate increased moisture availability. In addition, numerous other small, 657 shallow lakes in Alaska began accumulating sediment between 15 and 13 ka (e.g., Ager, 658 1982; Bigelow, 1997; 2001; Carlson and Finney, 2004). In summary, available evidence 659 suggests that the landscape response to a more amiable climate may explain the reduction 660 in dust input to Burial Lake during the deglacial transition. S-Ratios make a brief return 661 to higher values between 12.6 and $9.8 \mathrm{ka}$, broadly coinciding with a period of fluctuating 662 water levels in Birch Lake (Fig.9; Abbott et al., 2000). Lower water levels in Lake of the 663 Pleistocene (Nikivlik Lake) on the Arctic Foothills between 11,000 to $10,000{ }^{14} \mathrm{C}$ yr BP 664 ( 12,900 to $\sim 11,600$ cal yr BP; Mann et al., 2002) indicate a return to slightly drier 665 conditions and increasing dustiness during the later stages of the transition. Bigelow et al. 666 (1990) identified an increase in wind intensity between 13 and $12.6 \mathrm{ka}$ from grain size 667 variations in loess sequences along the Nenana River, which is in general agreement with 668 this period of renewed dust deposition at Burial Lake.

669 Unlike the relationship observed in theglacial period, the glacial chronology of the 670 Brooks Range during the transition is at times in phase with S-Ratios, and therefore we 671 are unable to rule out alpine glaciers as potential mediators of dustiness in the Noatak 672 Basin. The time-distance diagram for glaciers in the Brooks Range (Fig.9; Briner and 673 Kaufman, 2008) demonstrates that Itkillik II advances had largely withdrawn by the time 674 of the first drop inS-Ratios at $16 \mathrm{ka}$. Accordingly, Hamilton (1982) observed that 675 alluviation of outwash streams in the Koyakuk River area on the south side of the range 676 had ceased by $15 \mathrm{ka}$. Cosmogenic ${ }^{10} \mathrm{Be}$ exposure dating within the Kurupa and Antigun 677 River valleys in the north-central Brooks Range shows evidence for ice retreat from the 678 northern range prior to $15.9 \mathrm{ka}$, with glaciers disappearing entirely, or retreating into 679 individual cirques by 13.8 ka (Fig.9; Badding et al., 2012). Diminished glacial silt 680 production from local glaciers could therefore elucidate the major coercivity change that 681 we observe in Burial Lake at around the same time. Still, this would imply that dust from 682 nearby glaciers is magnetically distinct from terrestrial runoff derived from the same 683 general area (i.e.,lowcoercivity vs.highcoercivity), a perplexity that leads us to favor a 684 more widespread or far-field diminishing source of dust. The lack of evidence for ice 
685 advance between 12.6 and $9.8 \mathrm{ka}$, suggests that general aridity and an increase in wind 686 intensity are more likely responsible for dust emissions during this time.

687 Rising sea level and the rapid inundation of continental shelves may be largely 688 responsible for a reduction in far-field derived dust input to Burial Lake, and also may 689 explain the delayed response of S-Ratios from the start of the deglacial transition and the 690 initial rise in summer insolation (Fig.9). Although sea level began to rise $\sim 21$ ka (Fig. 9; 691 Clark et al., 2009), S-Ratios do not appear to respond until $16 \mathrm{ka}$. The corresponding $\sim 18$ $692 \mathrm{~m}$ rise in sea level, however, translates to a rather small surface area reduction of the 693 continental shelf, thus subtracting little from their total potential generation of dust. This 694 is well illustratedinFigure 10, which shows paleo shorelines contoured according to the 695 timing of major changes in S-Ratios, constructed usingglobal multi-resolution topography 696 (GMRT) from Ryan et al., (2009) and sea level estimates from Clark et al., (2009). The $697 \sim 45 \mathrm{~m}$ of rise between 16 and $12 \mathrm{ka} \mathrm{(Fig.} \mathrm{9),} \mathrm{however,} \mathrm{inundated} \mathrm{a} \mathrm{significant} \mathrm{portion} \mathrm{of}$ 698 Beringia (Fig. 10), and likely had a greater impact on dust availability and the magnetic 699 proportions in Burial Lake. While sea level appears to maintain a higher order control on 700 dust availability, it does not fully describe S-Ratios over the entirety of the transition. 701 For example, the return to slightly drier and dustier conditions at Burial Lake between 70212.6 and 9.8 ka occurs despite a $\sim 22 \mathrm{~m}$ rise in sea level (Fig. 9), and a significant loss in 703 land area (Fig. 10). Regional glacial isostatic adjustment(GIA) may have had significant 704 effects on paleo-topography during the deglacial transition (Milne and Mitrovica, 2008), 705 and should ultimately be considered in any quantitative evaluations of the timing and area 706 extent of potential dust sources on continental shelves with respect to sea level rise. 707

708 The Holocene(Subunit 3) $9.8 \mathrm{ka}$ - present

709 S-Ratios decrease again between 9.8 and $6.7 \mathrm{ka}$, attaining their lowest values in 710 the mid-Holocene and implying a continued diminishing input of dust (Fig. 8). Values 711 remain low and stable throughout the mid-Holocene, but increase again between $\sim 2 \mathrm{ka}$ 712 and the present, suggesting a slight recent intensification of dustiness in the late Holocene 713 (Fig. 8). Low CT density and low magnetic concentration observed throughout the 714 Holocene interval (Fig. 8) is interpreted largely as a function of dilution from high 715 organic matter and rising BSi as well asreduced input of themagnetically stronger low 
716 coercivity fraction (Fig. 8). Along with the general abundance of terrestrial macrofossils

717 for AMS radiocarbon analysis (Fig. 3), these data are characteristic of a warmer, more

718 quiescent Holocene environment, with increased terrestrial and aquatic productivity, and

719 enhanced precipitation.

720 Proxy data from Burial Lake support existing evidence for continued climatic 721 amelioration during the Holocene. The peak in organic content at $\sim 10.5 \mathrm{ka}$ (just before 722 the Holocene interval; Fig. 8) roughly coincides with peak summer insolation at (Fig.9;

723 Berger and Loutre, 1991) and with the reopening of the Bering Strait around 11 ka (Elias

724 et al., 1997), which likely facilitated the transport of maritime air masses into interior

725 Alaska. Birch Lake displays evidence for rising lake levels, approaching overflow

726 conditions between 10 and 9 ka (Fig.9), indicating an increase in effective moisture

727 (Abbott et al., 2000). These conditions are again likely to have prevented landscape

728 deflation, further reducing dust emissions, and contributing to the early to mid-Holocene

729 decline in S-Ratios.

730 Following the readvance of glaciers between 15.1 and 13.3 ka (Fig. 9; Hamilton, 731 2003), no further Itkillik II glacial activity is reported for the Brooks Range (Fig.9). The 732 decline in S-Ratios between 9.8 and 6.7 ka (Fig. 9), therefore cannot represent the 733 immediate cessation of dust production from glacial abrasion. The continued alluviation 734 of material from glacial catchments following retreat could have contributed a local 735 source of dust to Burial Lake, which would have declined over time as source material 736 dwindled. However, Hamilton $(1986 ; 2009)$ observed that post-Itkillik basin-filling had 737 commenced by $\sim 12.5 \mathrm{ka}$ in some valleys of the central Brooks Range - too early to fully 738 explain the decline in S-Ratios that extends well into the mid-Holocene.

739 Given the gentle sloping topography of the remaining portions of the Beringian 740 Steppe, sea level rise, on the order of $37 \mathrm{~m}$ between 9.8 and 6.7 ka (Fig. 9; Clark et al., 741 2009), corresponded to a massive reduction in land area (Fig. 10), and could very well 742 explain the early to mid-Holocene decline in dust input at Burial Lake. Though paleo743 shorelines are binned from $10 \mathrm{ka}$ to present in Figure 10, nearly all of the remaining area 744 was inundated before $\sim 7 \mathrm{ka}$, when sea level stabilized and Alaskan shorelines approached 745 their present-day configurations. Intriguingly, S-Ratios stabilize around the same time 746 (Fig.9), hinting at a possible causal relationship. Sea level rise, however, is likely not the 
747 sole cause of dust emissions in the Holocene, given that the late Holocene increase in S-

748 Ratios $\sim 2$ ka, occurs after sea level had already stabilized (Fig. 9).

749 This recent intensification of dustiness implied by increasing S-Ratios from $\sim 2 \mathrm{ka}$

750 is also difficult to rationalize given the available proxy evidence that indicates generally

751 wet and warm climatic conditions for central Alaska in the last few millennia (e.g. Abbott

752 et al., 2000; Kurek et al., 2009). Other than S-Ratios, down-core physical, geochemical,

753 and magnetic parameters do not appear to show any substantial deviation that would

754 indicate a sudden trend towards a more arid environment (Fig. 8). Sedimentation rates do

755 increase towards the late Holocene (Fig. 3), but this does not appear to be linked to an

756 increase in calculated detrital flux. Water levels at Birch Lake appear stable, at near-

757 overflow level (Fig.9), with sedimentary evidence suggesting a late Holocene moist

758 phase persisting throughout the last $\sim 5.5 \mathrm{ka}$ (Abbott et al., 2000). Summer insolation and

759 NGRIP $\delta^{18} \mathrm{O}$ do exhibit declining trends which are in phase with S-Ratios (Fig. 9), but as

760 the only supporting evidence for deteriorating climatic conditions in the recent past, we

761 do not suspect they contributed much towards the suddenly dustier conditions.

762 Cosmogenic ${ }^{10} \mathrm{Be}$ exposure dates provided by Badding et al. (2013) demonstrate 763 that late Holocene (Neoglacial) advances took place in the Kurupa and Antigun River 764 valleys, which formed pre-LIA (Little Ice Age) moraine crests between 4.6 and $2.7 \mathrm{ka}$ 765 (Fig.9). This is in agreement with previously published lichen-inferred ages (Ellis and 766 Calkin, 1984), which confirm that glaciers in the Brooks Range experienced multiple 767 similar Neoglacial advances (Fig.9). It is conceivable then, that these Neoglacial 768 advances supplied Burial Lake with local aeolian material, triggering the late Holocene 769 increase in S-Ratios. Barclay et al. (2009) report Neoglacial advances for glaciers in 770 southeast Alaska occurring as early as $4.5-4.0 \mathrm{ka}$, with major advances underway by 3.0 771 ka. They also describe the subsequent LIA advance as the largest Holocene expansion in 772 southern Alaska, with ice-volumes sufficiently large enough to cause major glacio773 isostatic depression and rebound (Larsen et al., 2005). Since the largest glaciers and ice 774 fields of Alaska are confined to southern mountain ranges (and glaciers are more limited 775 in the Brooks Range), we must consider them a potential far-field, glaciogenic source of 776 dust to Burial Lake. Though we are currently unable to magnetically fingerprint such a 
777 source, it may better conform to our description of a lowcoercivity mineralogy (Cowan et

778 al., 2006), than does known highcoercivity material from the Brooks Range.

779

780

\subsection{Conclusions}

781

We extend our understanding of paleo-environmental variability across the

782

Alaskan Arctic through a detailed study of Burial Lake sediments. This 37,000-

783 yearrecord can be subdivided into three lithologic subunits based on observed physical,

784 geochemical, and rock magnetic changes. The marked decrease in magnetic 785 concentration observed through the deglacial transition, is partly attributed to

786 biogenic/organic dilution as cold, windy, and dry glacial period conditions gave way to a 787 warmer, more productive Holocene climate with increased moisture availability. The 788 two main detrital constituents of Burial Lake sediments are mineralogically distinct and 789 can be classified according to their rock magnetic characteristics. The lowcoercivity 790 magnetic component is interpreted as magnetite-rich sediment that arrives via aeolian 791 deposition of dust. The highcoercivity component is interpreted as a local influx of 792 detrital minerals, weathered from surrounding bedrock, and arriving via terrestrial 793 seasonal runoff. Down-core rock magnetic variability indicates significant provenance 794 changes, which we suspect are mainly driven by variable inputs of aeolian dust. The 795 diminished relative contribution of the lowcoercivity ferrimagnetic componentfrom the 796 glacial period to the Holocene, along with a significant reduction in detrital flux, suggests

797 the decrease in magnetic concentration is also largely attributed to a decrease in clastic 798 aeolian flux.

799 Taking advantage of a well-constrained chronology and a simple depositional 800 environment, we compare the timing and extent of aeolian deposition in Burial Lake with 801 regional proxy data to constrain regional and far-field sources of dust and identify the 802 possible forcing mechanisms that control its production, availability, transport, and

803 deposition. The climatic amelioration associated with the deglacial transition appears to 804 have limited landscape deflation that likely supplied Burial Lake with a widespread 805 source of dust during the glacial period. The similarity of S-Ratios to regional lake level

806 reconstructions suggests that dust input is regulated to a large degree by general aridity.

807 As a result, S-Ratios can be used elsewhere in Alaska to estimate dust flux and general 
808 aridity at a much higher resolution, adding a needed dimension to ongoing paleoclimate 809 research in Alaska.

810 Although the Alaskan loess is typically assumed to be glaciogenic in origin, we at

811 times observe little correlation between dust input to Burial Lake and regional glacial

812 activity. This suggests that regional glaciers in the Brooks Range may not be the sole, or

813 even major, contributors of dust to Burial Lake, or that the availability of dust for

814 transport and its timing of deposition is more broadly dependent on regional climate.

815 Lastly, the similarity of S-Ratios to relative sea level demonstrates the 816 significance of newly exposed continental shelves as a potential far-field source of dust to 817 interior Alaska. Future studies of terrestrial loess deposits should therefore consider 818 continental shelves as a viable source of dust, which may communicate valuable long819 range paleo-environmental signals.

820

\section{Acknowledgements}

822 This research was supported by the National Science Foundation under grant\# 823 NSF-ARC 0909545. We would like to thank Dr. Nathan Stansell for his help 824 withfieldwork at Burial Lake in 2010, Jacques Labrie and Sylvain Leblanc atISMER for 825 their assistance with u-channel measurements and data processing,the staff at INRS-ETE 826 for their assistance with CT scanning, Dr. Bernard Housen and Russell Burmester at 827 Western Washington University for the use of their facilities and rock magnetic 828 instruments, and to our many colleagues and friends at CEOAS, particularly Dr. Alan 829 Mix and Dr. Anders Carlson for theirhelp and insight throughout this study. We also 830 thank the editor, and two anonymous reviewerswhose comments greatly improved this 831 manuscript.

832

\section{1.9References}

834 Abbott, M.B., Edwards, M.E., Finney, B.P., 2010. A 40,000-yr record of environmental 835 836 change from Burial Lake in Northwest Alaska. Quaternary Research 74, 156-165.

Abbott, M.B., Finney, B.P., Edwards, M.E., Kelts, K.R., 2000. Lake-Level Reconstruction and Paleohydrology of Birch Lake, Central Alaska, Based on Seismic 840 
841 Ager, T.A., 1975. Late quaternary environmental history of the Tanana Valley, Alaska. 842 Research Foundation and the Institute of Polar Studies, The Ohio State University, 843 Columbus, Ohio.

844

845

846

847

848

849

850

851

852

853

854

855

856

857

858

859

860

861

862

863

864

865

866

867

868

869

870

871

872

873

874

875

876

877

878

879

880

881

882

883

884

885

Anderson, N., Rippey, B., 1988. Diagenesis of magnetic minerals in the recent sediments of a eutrophic lake. Limnology and Oceanography 1476-1492.

Badding, M.E., Briner, J.P., Kaufman, D.S., 2013. 10Be ages of late Pleistocene deglaciation and Neoglaciation in the north-central Brooks Range, Arctic Alaska. J. Quaternary Sci. 28, 95-102.

Barclay, D.J., Wiles, G.C., Calkin, P.E., 2009. Holocene glacier fluctuations in Alaska. Quaternary Science Reviews 28, 2034-2048.

Begét, J.E., 1990. Middle Wisconsinan Climate Fluctuations Recorded in Central Alaskan Loess. Géographie physique et Quaternaire 44, 3-13.

Begét, J.E., 2001. Continuous Late Quaternary proxy climate records from loess in Beringia. Quaternary Science Reviews 20, 499-507.

Begét, J.E., Stone, D.B., Hawkins, D.B., 1990. Paleoclimatic forcing of magnetic susceptibility variations in Alaskan loess during the late Quaternary. Geology 18, 4043.

Berger, A., Loutre, M.F., 1991. Insolation values for the climate of the last 10 million years. Quaternary Science Reviews 10, 297-317.

Bigelow, N., Begét, J., Powers, R., 1990. Latest Pleistocene increase in wind intensity recorded in eolian sediments from central Alaska. Quaternary Research 34, 160-168.

Bigelow, N.H., 1997. Late-Quaternary climate and vegetation in interior Alaska. University of Alaska, Fairbanks, Fairbanks, AK.

Bigelow, N.H., Edwards, M.E., 2001. A 14,000 yr paleoenvironmental record from Windmill Lake, Central Alaska: Lateglacial and Holocene vegetation in the Alaska range. Quaternary Science Reviews 20, 203-215.

Bird, B., Abbott, M., Finney, B., Kutchko, B., 2009. A 2000 year varve-based climate record from the central Brooks Range, Alaska. J Paleolimnol 41, 25-41.

Blaauw, M., 2010. Methods and code for "classical" age-modelling of radiocarbon sequences. Quaternary Geochronology 5, 512-518.

Blott, S.J., Pye, K., 2001. GRADISTAT: a grain size distribution and statistics package for the analysis of unconsolidated sediments. Earth Surf. Process. Landforms 26, $1237-1248$. 
Briner, J.P., Kaufman, D.S., 2008. Late Pleistocene mountain glaciation in Alaska: key

Broecker, W.S., 1994. Massive iceberg discharges as triggers for global climate change. Nature 372, 421-424.

Canfield, D.E., and Berner, R.A., 1987, Dissolution and pyritization of magnetite in anoxic marine sediments: Geochimica et Cosmochimica Acta, v. 51, p. 645-659.

Carlson, L.J., Finney, B.P., 2004. A 13 000-year history of vegetation and environmental change at Jan Lake, east-central Alaska. Holocene 14, 818-827.

Clark, P.U., Dyke, A.S., Shakun, J.D., Carlson, A.E., Clark, J., Wohlfarth, B., Mitrovica, J.X., Hostetler, S.W., McCabe, A.M., 2009. The Last Glacial Maximum. Science 325, $710-714$.

Clark, P.U., Shakun, J.D., Baker, P.A., Bartlein, P.J., Brewer, S., Brook, E., Carlson, A.E., Cheng, H., Kaufman, D.S., Liu, Z., Marchitto, T.M., Mix, A.C., Morrill, C., Otto-Bliesner, B.L., Pahnke, K., Russell, J.M., Whitlock, C., Adkins, J.F., Blois, J.L., Clark, J., Colman, S.M., Curry, W.B., Flower, B.P., He, F., Johnson, T.C., LynchStieglitz, J., Markgraf, V., McManus, J., Mitrovica, J.X., Moreno, P.I., Williams, J.W., 2012. Global climate evolution during the last deglaciation. Proceedings of the National Academy of Sciences.

Cowan, E. A., Brachfeld, S. A., Powell, R. D., Schoolfield, S. C., 2006. Terrane-specific rock magnetic characteristics preserved in glacimarine sediment from southern coastal Alaska. Canadian Journal of Earth Sciences, 43, 1469-1282.

Davies, M.H., Mix, A.C., Stoner, J.S., Addison, J.A., Jaeger, J., Finney, B., Wiest, J., 2011. The deglacial transition on the southeastern Alaska Margin: Meltwater input, sea level rise, marine productivity, and sedimentary anoxia. Paleoceanography 26 , PA2223.

Day, R., Fuller, M., Schmidt, V., 1977. Hysteresis properties of titanomagnetites: grainsize and compositional dependence. Physics of the Earth and Planetary Interiors 13, 260-267.

Dekkers, M.J., 1997. Environmental magnetism: an introduction. Geologie en Mijnbouw $76,163-182$.

Duchesne, M.J., Moore, F., Long, B.F., Labrie, J., 2009. A rapid method for converting medical computer tomography scanner topogram attenuation scale to Hounsfield unit scale and to obtain relative density values. Engineering Geology 103, 100-105.

Dunlop, D.J., Özdemir, Ö., 2001. Rock magnetism: fundamentals and frontiers. Cambridge University Press. 
933 Elias, S.A., Hamilton, T.D., Edwards, M.E., Begét, J.E., Krumhardt, A.P., Lavoie, C., 934 1999. Late Pleistocene environments of the western Noatak basin, northwestern $935 \quad$ Alaska. Bull Geol Soc Am 111, 769-789.

936

937 Land Bridge. Palaeogeography, Palaeoclimatology, Palaeoecology 136, 293-308.

Ellersieck, I., Curtis, S.M., Mayfield, C.F., and Tailleur, I.L., 1984, Reconnaissance geologic map of south-central Misheguk Mountain Quadrangle, Alaska: U.S. Geological Survey Miscellaneous Investigations Series Map 1504, 2 sheets, scale 1:63,360.

Ellis, J.M., Calkin, P.E., 1984. Chronology of Holocene glaciation, central Brooks Range, Alaska. Geological Society of America Bulletin 95, 897-912.

Evans, M.E., Jensen, B.J.L., Kravchinsky, V.A., Froese, D.G., 2011. The Kamikatsura event in the Gold Hill loess, Alaska. Geophys. Res. Lett. 38, L13302.

Evans, M.M.E., Heller, F.A., 2003. Environmental magnetism:, International geophysics series. Academic Press, Incorporated.

Farrians, O., J., 1965. Permafrost map of Alaska: U.S. Geological Survey Miscellaneous Geologic Investigations Map I-445.

Finkenbinder, M.S. Abbott, M.B., Steinman, B.A., Edwards, M.E., Langdon, C.T., and Finney, B.P. (2014). A 31,000 Year Record of Paleoenvironmental and Lake-Level Change from Harding Lake, Alaska, USA. Quaternary Science Reviews 87, 98-113.

Finkenbinder, M.S., Abbott, M.B., Stoner, J.S., Dorfman, J.M.,(this issue), A multidecadal to centennial scale multi-proxy reconstruction of environmental change spanning the last 37,000 years from Burial Lake, Arctic Alaska. Quaternary Science Reviews.

Fortin, D., Francus, P., Gebhardt, C. Hahn, A., Kliem, P., Labrie, J., Lise-Pronovost*, A., Roychowdhury, R., St-Onge, G., Zolitschka, B., and the PASADO Science Team, 2013. Density variability of the PASADO long composite record: method comparison and interpretation. Quaternary Science Reviews 71, 147-153.

Frank, U., Nowaczyk, N.R., 2008. Mineral magnetic properties of artificial samples systematically mixed from haematite and magnetite. Geophysical Journal International 175, 449-461.

Hamilton, T.D., 1982. A late Pleistocene glacial chronology for the southern Brooks Range: Stratigraphic record and regional significance. Geological Society of America Bulletin 93, 700-716.

978 
979

980

981

982

983

984

985

986

987

988

989

990

991

992

993

994

995

996

997

998

999

1000

1001

1002

1003

1004

1005

1006

1007

1008

1009

1010

1011

1012

1013

1014

1015

1016

1017

1018

1019

1020

1021

1022

1023

Hamilton, T.D., 1994, Late Cenozoic glaciation of Alaska, in Plafker, George, and Berg, H.C., The Geology of Alaska: Geological Society of America, p. 813-844.

Hamilton, T.D., 2001. Quaternary glacial, lacustrine, and fluvial interactions in the western Noatak basin, Northwest Alaska. Quaternary Science Reviews 20, 371-391.

Hamilton, T.D., 2003. Surficial geology of the Dalton Highway (Itkillik-Sagavanirktok Rivers) area, southern Arctic foothills, Alaska. Alaska Dept. of Natural Resources, Division of Geological and Geophysical Surveys, [Fairbanks, Alaska].

Hamilton, T.D., 2009, Guide to surficial geology and river-bluff exposures, Noatak National Preserve, northwestern Alaska: U.S. Geological Survey Scientific Investigations Report 2008-5125, 116 p. [http://pubs.usgs.gov/sir/2008/5125/].

Hamilton, T.D., 2010, Surficial geologic map of the Noatak National Preserve, Alaska: U.S. Geological Survey Scientific Investigations Map 3036, 1 sheet, scale 1:250,000, 1 pamphlet, $21 \mathrm{p}$.

Hamilton, T.D., and Labay, K.A., 2011, Surficial geologic map of the Gates of the Arctic National Park and Preserve, Alaska: U.S. Geological Survey Scientific Investigations Map 3125, pamphlet 19 p., scale 1:300,000, available at http://pubs.usgs.gov/sim/3125/.

Hamilton, T.D., Van Etten, D.P., 1984. Late Pleistocene glacial dams in the Noatak valley. In: Coonrad, W.L., Elliott, R.L. (Eds.), The United States Geological Survey in Alaska: Accomplishments During 1981. U.S. Geol. Survey Circular 868, pp. 2123.

Hatfield, R.G. \& J.S. Stoner, 2013: Magnetic Proxies and Susceptibility In: Elias S.A. (ed.) The Encyclopedia of Quaternary Science, vol. 2, pp. 884-898. Amsterdam: Elsevier.

Heslop, D., Dekkers, M.J., Kruiver, P.P., Van Oorschot, I.H.M., 2002. Analysis of isothermal remanent magnetization acquisition curves using the expectationmaximization algorithm. Geophysical Journal International 148, 58-64.

Hopkins, D.M., 1982. Aspects of the paleogeography of Beringia during the late Pleistocene. Paleoecology of Beringia. Academic Press, New York 3-28.

Hostetler, S.W., Clark, P.U., Bartlein, P.J., Mix, A.C., Pisias, N.J., 1999. Atmospheric transmission of North Atlantic Heinrich events. J. Geophys. Res. 104, 3947-3952.

Hounsfield, G.N., 1973. Computerized transverse axial scanning (tomography): I.description of system. British Journal of Radiology 46 (552), 1016e1022. 
1024 Hutchins, D.A., Bruland, K.W., 1998. Iron-limited diatom growth and Si:N uptake ratios in a coastal upwelling regime. Nature 393, 561-564.

1026

1027

1028

1029

1030

1031

1032

1033

1034

1035

1036

1037

1038

1039

1040

1041

1042

1043

1044

1045

1046

1047

1048

1049

1050

1051

1052

1053

1054

1055

1056

1057

1058

1059

1060

1061

1062

1063

1064

1065

1066

1067

1068

1069
Huybers, P., Wunsch, C., 2004. A depth-derived Pleistocene age model: Uncertainty estimates, sedimentation variability, and nonlinear climate change. Paleoceanography 19, PA1028.

Imbrie, J., Northwestern University (Evanston, I.), Research, U.S.O. of N., 1963. Factor and Vector Analysis Programs for Analyzing Geologic Data. Northwestern University.

Karlin, R., and Levi, S., 1983. Diagenesis of magnetic minerals in recent hemipelagic sediments. Nature 303: 327-330.

King, J.W., and Channel, J.E.T., 1991, Sedimentary magnetism, environmental magnetism, and magnetostratigraphy: Reviews of Geophysics, Supplement, p. 358370.

Kohfeld, K.E., Harrison, S.P., 2001. DIRTMAP: the geological record of dust. EarthScience Reviews 54, 81-114.

Kurek, J., Cwynar, L.C., Ager, T.A., Abbott, M.B., Edwards, M.E., 2009. Late Quaternary paleoclimate of western Alaska inferred from fossil chironomids and its relation to vegetation histories. Quaternary Science Reviews 28, 799-811.

Lagroix, F., Banerjee, S.K., 2002. Paleowind directions from the magnetic fabric of loess profiles in central Alaska. Earth and Planetary Science Letters 195, 99-112.

Larsen, C.F., Motyka, R.J., Freymueller, J.T., Echelmeyer, K.A., Ivins, E.R., 2005. Rapid viscoelastic uplift in southeast Alaska caused by post-Little Ice Age glacial retreat. Earth and Planetary Science Letters 237, 548-560.

Liu, X.M., Hesse, P., Rolph, T., Begét, J.E., 1999. Properties of magnetic mineralogy of Alaskan loess: evidence for pedogenesis. Quaternary International 62, 93-102.

Mann, D.H., Peteet, D.M., Reanier, R.E., Kunz, M.L., 2002. Responses of an arctic landscape to Lateglacial and early Holocene climate changes: the importance of moisture. Quaternary Science Reviews 21, 997-1021.

Marcott, S.A., Shakun, J.D., Clark, P.U., Mix, A.C., 2013. A Reconstruction of Regional and Global Temperature for the Past 11,300 Years. Science 339, 1198-1201.

Mayfield, C.F., Curtis, S.M., Ellersieck, I., and Tailleur, I.L., 1984, Reconnaissance geologic map of southeastern Misheguk Mountain Quadrangle, Alaska: U.S. Geological Survey Miscellaneous Investigations Series Map 1503, 2 sheets, scale $1: 63,360$. 
1070

1071

1072

1073

1074

1075

1076

1077

1078

1079

1080

1081

1082

1083

1084

1085

1086

1087

1088

1089

1090

1091

1092

1093

1094

1095

1096

1097

1098

1099

1100

1101

1102

1103

1104

1105

1106

1107

1108

1109

1110

1111

1112

1113

1114

1115

Milne, G. A., and J. X. Mitrovica, 2008. Searching for eustasy in deglacial sea-level histories, Quaternary Science Reviews, 27, 2292-2302.

Mikolajewicz, U., Crowley, T.J., Schiller, A., Voss, R., 1997. Modelling teleconnections between the North Atlantic and North Pacific during the Younger Dryas. Nature 387, 384-387.

Muhs, D.R., Ager, T.A., Arthur Bettis III, E., McGeehin, J., Been, J.M., Begét, J.E., Pavich, M.J., Stafford Jr., T.W., Stevens, D.A.S.P., 2003a. Stratigraphy and palaeoclimatic significance of Late Quaternary loess-palaeosol sequences of the Last Interglacial-Glacial cycle in central Alaska. Quaternary Science Reviews 22, 19471986.

Muhs, D.R., Ager, T.A., Been, J., Bradbury, J.P., Dean, W.E., July 2003b. A late quaternary record of eolian silt deposition in a maar lake, St. Michael Island, western Alaska. Quaternary Research 60, 110-122.

Muhs, D.R., Budahn, J.R., 2006. Geochemical evidence for the origin of late Quaternary loess in central Alaska. Can. J. Earth Sci. 43, 323-337.

North Greenland Ice Core Project members, 2004. High-resolution record of Northern Hemisphere climate extending into the last interglacial period. Nature 431, 147-151.

Oswald, W.W., Anderson, P.M., Brown, T.A., Brubaker, L.B., Feng Sheng Hu, Lozhkin, A.V., Tinner, W., Kaltenrieder, P., 2005. Effects of sample mass and macrofossil type on radiocarbon dating of arctic and boreal lake sediments. Holocene 15, 758-767.

Péwé, T.L., 1955. Origins of the upland silt near Fairbanks, Alaska. Geological Society of America Bulletin 66, 699-724.

Praetorius, S.K. \& Mix, A.C. 2014. Synchronization of North Pacific and Greenland climates preceded abrupt deglacial warming. Science 345, 444-448.

Rasmussen, S.O., Andersen, K.K., Svensson, A.M., Steffensen, J.P., Vinther, B.M., Clausen, H.B., Siggaard-Andersen, M.-L., Johnsen, S.J., Larsen, L.B., Dahl-Jensen, D., Bigler, M., Röthlisberger, R., Fischer, H., Goto-Azuma, K., Hansson, M.E., Ruth, U., 2006. A new Greenland ice core chronology for the last glacial termination. J. Geophys. Res. 111, D06102.

Rea, D.K., 1994. The paleoclimatic record provided by eolian deposition in the deep sea: The geologic history of wind. Rev. Geophys. 32, 159-195.

Reimer, P.J., Baillie, M.G.L., Bard, E., Bayliss, A., Beck, J.W., Blackwell, P.G., Ramsey, C.B., Buck, C.E., Burr, G.S., Edwards, R.L., Friedrich, M., Grootes, P.M., Guilderson, T.P., Hajdas, I., Heaton, T.J., Hogg, A.G., Hughen, K.A., Kaiser, K.F., Kromer, B., McCormac, F.G., Manning, S.W., Reimer, R.W., Richards, D.A., 
1116

1117

1118

1119

1120

1121

1122

1123

1124

1125

1126

1127

1128

1129

1130

1131

1132

1133

1134

1135

1136

1137

1138

1139

1140

1141

1142

1143

1144

1145

1146

1147

1148

1149

1150

1151

1152

1153

1154

1155

1156

1157

1158

1159

1160

1161

Southon, J.R., Talamo, S., Turney, C.S.M., Plicht, J. van der, Weyhenmeyer, C.E., 2011. IntCal09 and Marine09 Radiocarbon Age Calibration Curves, 0-50,000 Years cal BP. Radiocarbon 51, 1111-1150.

Rowan, C.J. et al., 2009. Reductive diagenesis, magnetite dissolution, greigite growth and paleomagnetic smoothing in marine sediments: A new view. EPSL, Vol. 227, 223235.

Ryan, W.B.F., Carbotte, S.M., Coplan, J.O., O'Hara, S., Melkonian, A., Arko, R., Weissel, R.A., Ferrini, V., Goodwillie, A., Nitsche, F., Boncz-kowski, J., and Zemsky, R., 2009, Global multi-resolution topography synthesis: Geochemis-try Geophysics Geosystems, v. 10, Q03014, doi:10.1029/2008GC002332.

Slack, J.F., Dumoulin, J.A., Schmidt, J.M., Young, L.E., Rombach, C.S., 2004. Paleozoic Sedimentary Rocks in the Red Dog Zn-Pb-Ag District and Vicinity, Western Brooks Range, Alaska: Provenance, Deposition, and Metallogenic Significance. Economic Geology 99, 1385-1414.

Snowball, I.F. 1993. Geochemical control of magnetite dissolution in sub-arctic lake sediments and the implications for environmental magnetism. Journal of Quaternary Science, 8, 339-346.

St-Onge, G., Stoner, J.S., Hillaire-Marcel, C., 2003. Holocene paleomagnetic records from the St. Lawrence Estuary, eastern Canada: centennial- to millennial-scale geomagnetic modulation of cosmogenic isotopes. Earth and Planetary Science Letters 209, 113-130.

Stober, J.C., Thompson, R., 1979. An investigation into the source of magnetic minerals in some Finnish lake sediments. Earth and Planetary Science Letters 45, 464-474.

Stoner, J.S., St-Onge, G., 2007. Chapter Three Magnetic Stratigraphy in Paleoceanography: Reversals, Excursions, Paleointensity, and Secular Variation. Developments in Marine Geology 1, 99-138.

Stuiver, M. and Polach, H.A., 1977. Discussion: Reporting of 14C data. Radiocarbon, 19:355-363.

Stuiver, M., Reimer, P. J., and Reimer, R. W. 2005. CALIB 5.0. [program and documentation]. http://calib.qub.ac.uk/calib/

Tauxe, L., 1993. Sedimentary records of relative paleointensity of the geomagnetic field: theory and practice. Reviews of geophysics 31, 319-354.

Tegen, I., Lacis, A.A., Fung, I., 1996. The influence on climate forcing of mineral aerosols from disturbed soils. Nature 380, 419-422. 
1162 Thompson, R., Oldfield, F., 1986. Environmental Magnetism. Allen \& Unwin.

1163

1164

1165

1166

1167

1168

1169

1170

1171

1172

1173

1174
Viau, A.E., Gajewski, K., Sawada, M.C., Bunbury, J., 2008. Low- and high-frequency climate variability in eastern Beringia during the past 25000 years. Canadian Journal of Earth Sciences 45, 1435-1453.

Vlag, P.A., Oches, E.A., Banerjee, S.K., Solheid, P.A., 1999. The paleoenvironmentalmagnetic record of the Gold Hill Steps loess section in central Alaska. Physics and Chemistry of the Earth, Part A: Solid Earth and Geodesy 24, 779-783.

Xuan, C., Channell, J.E.T., 2009. UPmag: MATLAB software for viewing and processing u channel or other pass-through paleomagnetic data. Geochem. Geophys. Geosyst. 10, Q10Y07. 


\begin{tabular}{|c|c|c|c|c|c|c|c|}
\hline $\begin{array}{l}\text { Sample } \\
\text { ID } \\
\text { (UCIAMS \#) }\end{array}$ & Core-Drive & $\begin{array}{l}\text { Drive } \\
\text { Depth } \\
(\mathrm{cm})\end{array}$ & $\begin{array}{l}\text { Total } \\
\text { Depth } \\
(\mathrm{cm})\end{array}$ & Material & $\left({ }^{14} \mathrm{C}\right.$ yr $)$ & $(\mathrm{yr})$ & $\begin{array}{l}\text { Calib } 6.0 \\
\text { Age } \\
\text { (yr BP) }\end{array}$ \\
\hline 89197 & $A-10$ D1 & 45.0 & 45.0 & plant material & 2,535 & 30 & $2,493-2,745$ \\
\hline 109361 & $A-10$ D1 & 66.5 & 66.5 & wood & 3,635 & 25 & $3,872-4,074$ \\
\hline 116878 & $A-10 D 1$ & 87.5 & 87.5 & plant material & 4,910 & 90 & $5,470-5,896$ \\
\hline 89198 & A-10 D1 & 111.0 & 111.0 & plant material & 6,345 & 25 & $7,174-7,410$ \\
\hline 109362 & $A-10 D 1$ & 141.5 & 141.5 & wood & 8,850 & 110 & $9,564-10,205$ \\
\hline 89199 & $A-10$ D2 & 84.0 & 166.0 & plant material & 9,760 & 40 & $11,134-11,244$ \\
\hline 89200 & A-10 D3 & 54.0 & 173.5 & seed & 10,085 & 45 & $11,398-11,959$ \\
\hline 89122 & $C-10$ D3 & 45.0 & 219.0 & wood & 13,670 & 30 & $16,657-16,978$ \\
\hline * 109363 & A-10 D5 & 35.5 & 359.5 & plant material & 14,590 & 550 & $16,570-18,903$ \\
\hline 89201 & A-10 D7 & 29.0 & 553.0 & seed & 25,300 & 510 & $29,173-31,074$ \\
\hline * 89123 & $C-10 \mathrm{D} 7$ & 64.0 & 598.0 & plant material & 31,290 & 300 & $35,085-36,475$ \\
\hline 89124 & $C-10$ D7 & 72.0 & 606.0 & wood & 31,090 & 210 & $35,036-36,313$ \\
\hline 89121 & A-10 D8 & 35.5 & 636.5 & wood & 32,150 & 240 & $35,699-37,342$ \\
\hline
\end{tabular}

Table 1.AMS radiocarbon results based on terrestrial macrofossils identified in deep basin cores A10 and C10, which were stratigraphically correlated to produce the composite depth scale (see Figure 2). Radiocarbon ages were calibrated using Calib 6.0 (Stuiver et al., 2005) and the IntCal09 calibration curve (Reimer et al., 2009), and are reported at their $2 \sigma$ confidence levels.Samples highlighted with an asterisk $\left(^{*}\right)$ are omitted from the age model with explanations in the text. 


\begin{tabular}{|l|l|l|l|l|l|}
\hline $\begin{array}{c}\text { Sample } \\
\text { (Depth) }\end{array}$ & $\%$ Component 1 & \% Component 2 & $\begin{array}{l}\text { Mean Coercivity } \\
\text { Component 1 (mT) }\end{array}$ & $\begin{array}{l}\text { Mean coercivity } \\
\text { Component 2 (mT) }\end{array}$ & $\begin{array}{l}\text { Sum of Components } \\
1 \& 2 \mathrm{R}^{2} \text { correlation to } \\
\text { smoothed input data }\end{array}$ \\
\hline A $(40 \mathrm{~cm})$ & 68.2 & 31.8 & 44.1 & 176.6 & 0.995 \\
\hline $\mathrm{B}(80 \mathrm{~cm})$ & 43.4 & 56.6 & 38.0 & 105.6 & 0.972 \\
\hline $\mathrm{C}(130 \mathrm{~cm})$ & 74.7 & 25.3 & 42.1 & 239.1 & 0.994 \\
\hline $\mathrm{D}(170 \mathrm{~cm})$ & 89.3 & 43.5 & 303.7 & 0.998 \\
\hline $\mathrm{E}(190 \mathrm{~cm})$ & 87.8 & 12.2 & 41.0 & 287.0 & 0.997 \\
\hline $\mathrm{F}(241 \mathrm{~cm})$ & 94.1 & 5.9 & 42.0 & 339.2 & 0.996 \\
\hline $\mathrm{G}(384 \mathrm{~cm})$ & 56.1 & 43.9 & 44.2 & 60.2 & 0.992 \\
\hline $\mathrm{H}(474 \mathrm{~cm})$ & 93.0 & 7.0 & 47.7 & 314.6 & 0.995 \\
\hline $\mathrm{I}(574 \mathrm{~cm})$ & 80.6 & 19.4 & 231.5 & 0.987 \\
\hline
\end{tabular}

Table 2.Summary of IRM decomposition results for samples A-I assuming a two-component model. Relative percent contribution for components 1 and 2 are given for each sample along with their mean coercivities. $\mathrm{R}^{2}$ values are also given for the sum of components 1 and 2 compared against smoothed input data. Graphical results for samples H, E, and A are shown in Figure 7, representing Subunits 1, 2, and 3, respectively. Note samples B and G appear anomalous, which can be attributed to measurement noise and/or better representation using a three-component model (see text for further explanation). 


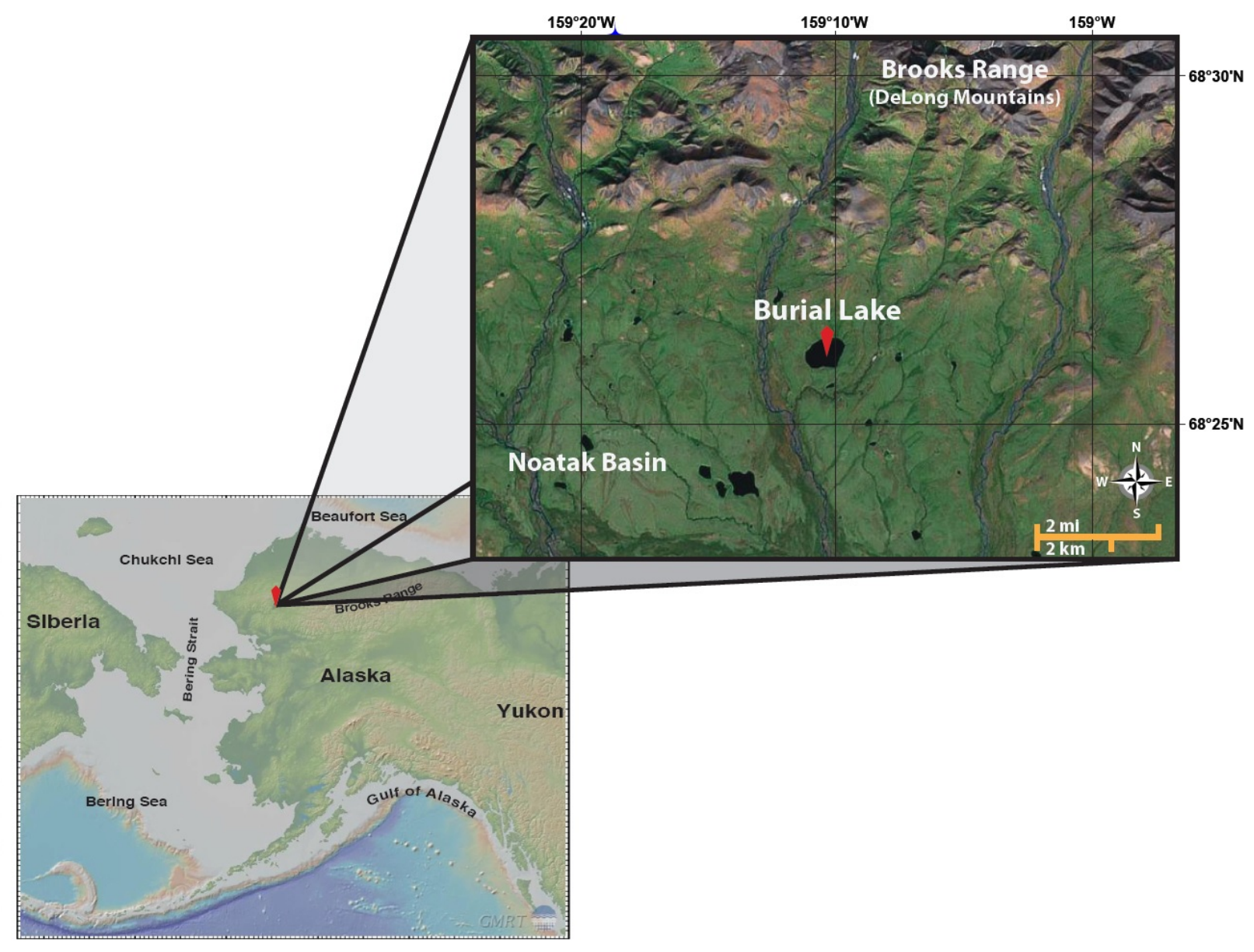

Figure 1.Site location map. Burial Lake $\left(68.43^{\circ} \mathrm{N}, 159.17^{\circ} \mathrm{W}\right)$ is located in Noatak Basin in the northwest Brooks Range, Arctic Alaska, at the foot of the DeLong Mountains. 


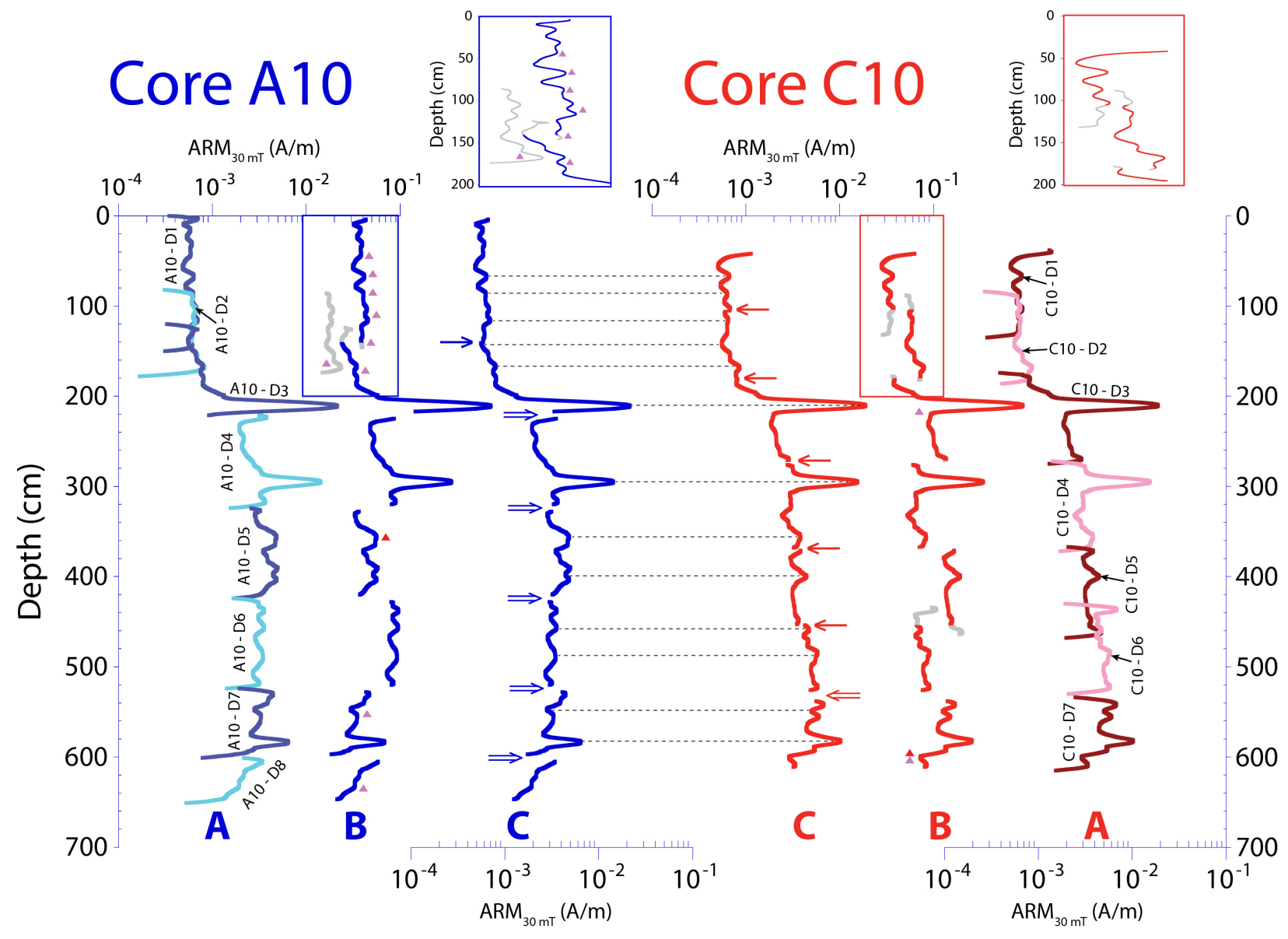

Figure 2. A stratigraphic comparison and composite depth scale construction for cores $A 10 / C 10$. ARM $\mathrm{AmT}_{30 \mathrm{~m}}$ values are plotted for cores A10 (left side) and C10 (right side) demonstrating their stratigraphic correlation on a common depth scale after C10 drives were "hung" to match the A10 record. Note, values are plotted on a log scale. A) Data for individual drives are shown in alternating colors, including magnetometer edge effects. B) Edge effects are removed and drives are offset to better show the alignment of features between overlapping drives. Grey segments show the drives or portions of drives that were not used in the final composite record of each core. Insets are shown for the upper $200 \mathrm{~cm}$ of each core (blue and red boxes), with values scaled to show variance. Locations of radiocarbon dates are shown, with pink triangles corresponding to accepted ages and red triangles corresponding to rejected ages. C) Data are recompiled to show the final composite record of each core. Locations of section breaks are shown for overlapping sections $(\rightarrow)$ and for sections that are either abutted or contain a data gap $(\Rightarrow)$. Tie points show the agreement of features between the final composite versions of each core. Note, the final C10 composite record is not utilized in this report, and we mainly focus on results from the $6.51 \mathrm{~m} \mathrm{~A} 10$ core. The stratigraphic correlation does, however, allow us to incorporate $\mathrm{C} 10$ radiocarbon dates in the age-depth model for the A10 core. 
Age (ka)

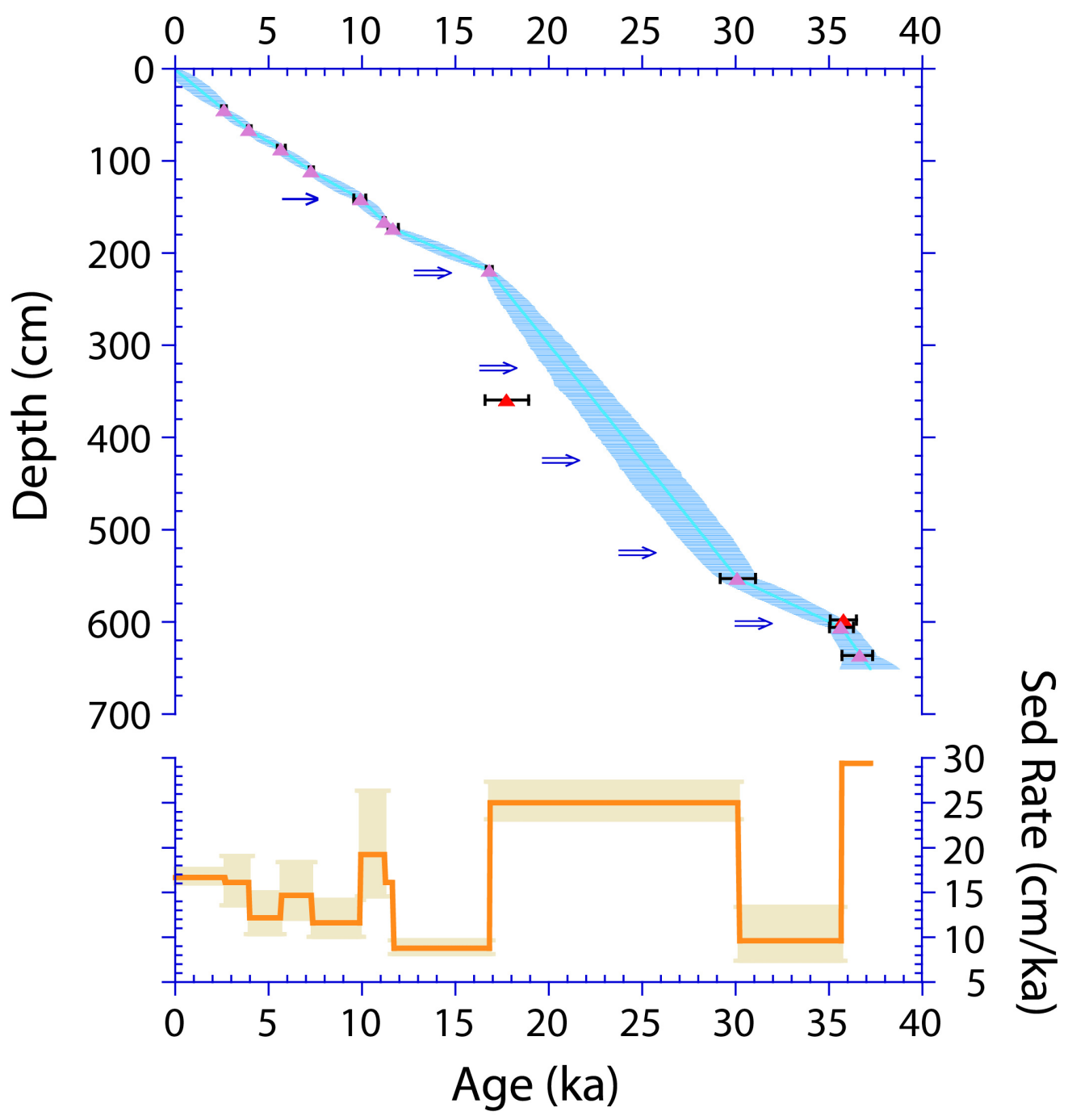

Figure 3.AMS radiocarbon results based on terrestrial macrofossils identified in deep basin cores A10 and C10, which were stratigraphically correlated to produce a composite depth scale. Radiocarbon ages were calibrated using Calib 6.0 (Stuiver et al., 2005) and the IntCal09 calibration curve (Reimer et al., 2009). Eleven calibrated median radiocarbon ages (pink triangles) are shown with associated $2 \sigma$ error bars, as well as two dates, which were excluded from the age model (red triangles - see text for explanation). CLAM software for "classical" non-Bayesian age-depth modeling (Blaauw, 2010) was used to produce the "best fit" linearly interpolated age (cyan line) for the $6.51 \mathrm{~m}$ A10 core. Locations of A10 section breaks are shown for overlapping $(\rightarrow)$ and abutted $(\Rightarrow)$ sections. The blue shaded envelope represents the maximum age variance computed between age control points based on the $2 \sigma$ calibrated ${ }^{14} \mathrm{C}$ ages. It is the maximum $\mathrm{AR} 1$ normalized $1 \sigma$ standard deviation computed from 10,000 Monte Carlo simulations following a random draw from a normal distribution (Marcott et al., 2013) with uncertainty between age control points based on a random walk model after Huybers and Wunsch, (2004), using a "jitter factor" of 200. The orange line represents sedimentation rate over the $\sim 37,000$-year time interval with uncertainty generated using the $2 \sigma$ calibrated age range of each age control point where feasible. 

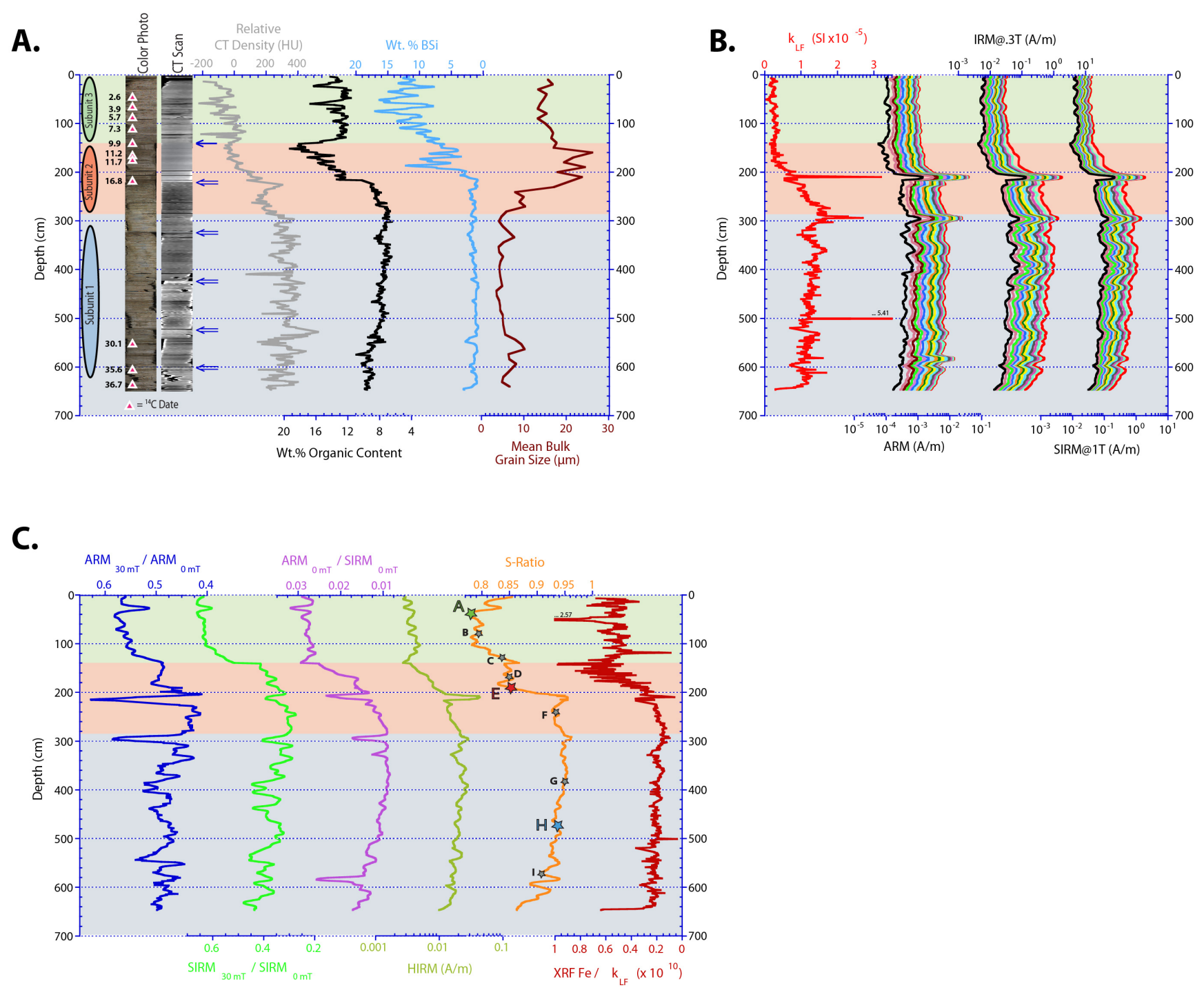

Figure 4.Down-core physical, geochemical, and magnetic properties versus depth. A) Physical and geochemical properties: (from left to right) Color photo with radiocarbon ages (pink triangles) for reference, Computer Tomography (CT) image with locations of A10 section breaks for overlapping $(\leftarrow)$ and abutted $(\Leftarrow)$ sections, relative CT density, organic content, biogenic silica $(\mathrm{BSi})$, and mean bulk physical grain size. Lithologic subunits are designated by color: Subunit 1 (blue) from 651-285 cm, Subunit 2 (red) from 285-140 cm, and Subunit 3 (green) from 140-0 cm. B) Concentration dependent magnetic parameters: magnetic susceptibility $\left(k_{\mathrm{LF}}\right)$, anhystereticremanent magnetization (ARM), isothermal remanent magnetization (IRM), and saturation isothermal remanent magnetization (SIRM), plotted with their respective alternating field (AF) demagnetization steps ranging from 10-80 mT.C) Magnetic ratios for coercivity/grain size/mineralogy: $\mathrm{ARM}_{30 \mathrm{mT}} / \mathrm{ARM}_{0 \mathrm{mT}}, \mathrm{SIRM}_{30 \mathrm{mT}} / \mathrm{SIRM}_{0 \mathrm{mT}}, \mathrm{ARM}_{0 \mathrm{mT}} / \mathrm{SIRM}_{0 \mathrm{mT}}$, hard isothermal remnant magnetization (HIRM), S-Ratios (stars and lettering indicate sample locations for IRM acquisition/decomposition, with enlarged colored symbols indicated representative samples from each subunit), and X-ray fluorescence (XRF) $\mathrm{Fe} / k_{\mathrm{LF}}$. Note some parameters are plotted on a log scale. 

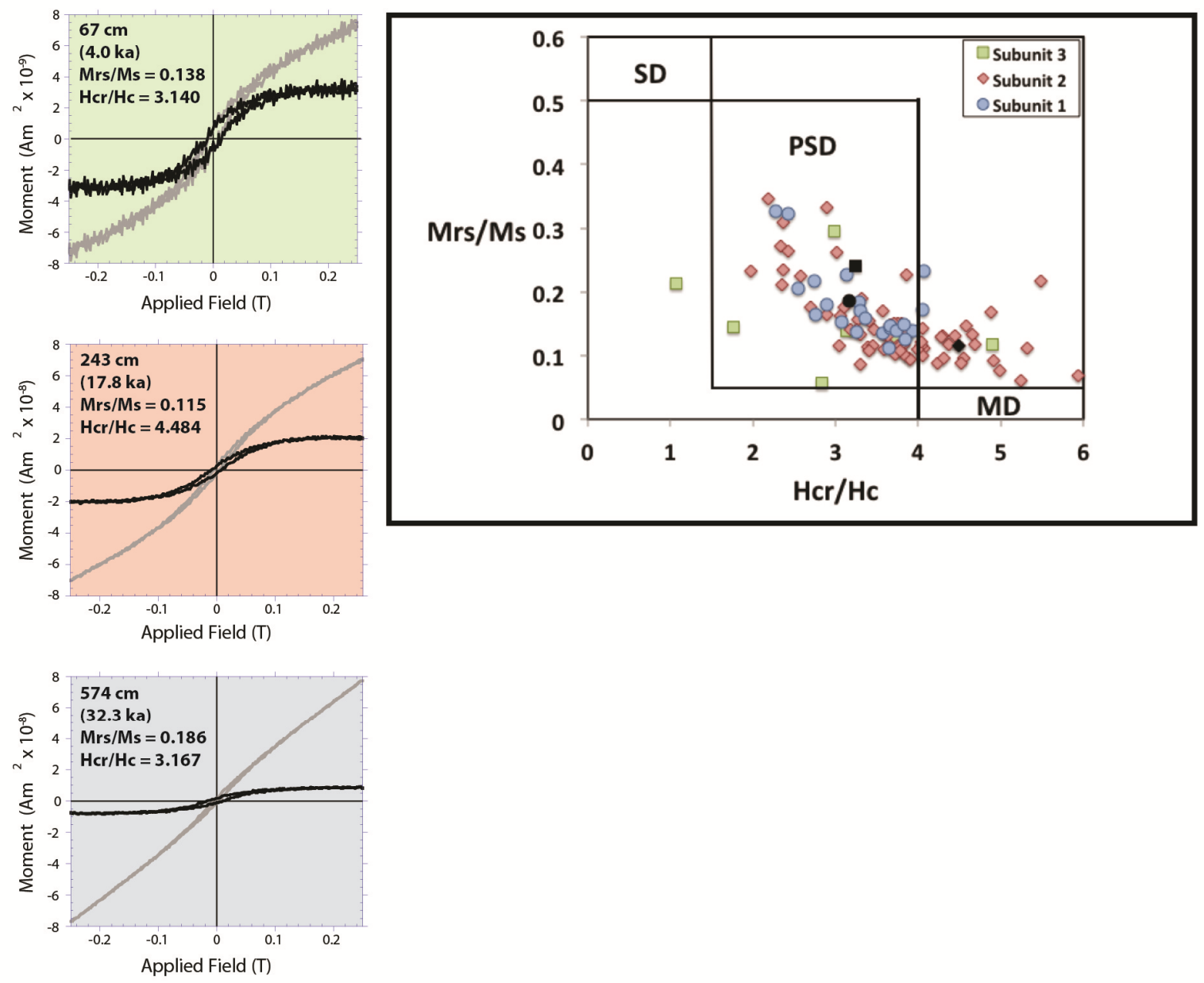

Figure 5.Hysteresis results. A) Hysteresis loops generated from alternating gradient force magnetometer (AGM) measurements on representative samples from each lithologic subunit. Uncorrected loops are shown (grey lines) as well as those corrected for high-field paramagnetic/diamagnetic contributions (black lines). Shapes of loops demonstrate the presence of low coercivityferrimagnetic minerals such as magnetite, and also exhibit paramagnetic contributions. Noisy loops in Subunit 3 are indicative of low ferrimagnetic magnetic concentration. B) Hysteresis ratios of Hcr/Hc and Mrs/Ms plotted according to Day et al. (1977) for a number of samples within each subunit, with theoretical domain state (magnetic grain size) boundaries drawn according to the behavior of pure magnetite (Day et al., 1977). Most samples fall within the PSD-MD magnetic grain size range including values derived from the hysteresis loops depicted here (black symbols), though scatter does occur - likely due to low ferrimagnetic concentration and/or high coercivity components. 


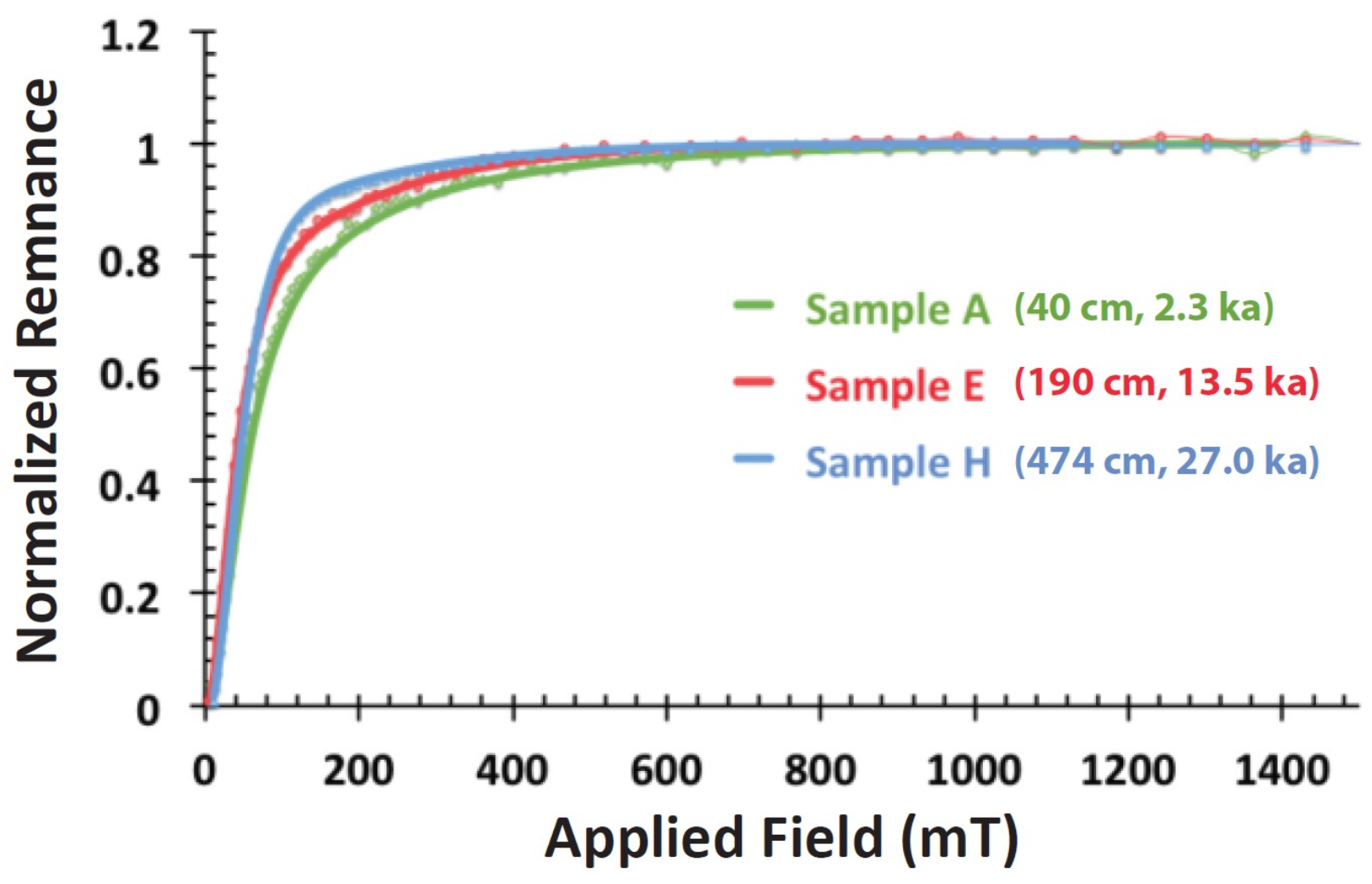

Figure 6. Representative normalized IRM acquisition curves from Subunit 1 (H: $474 \mathrm{~cm}, 27.0 \mathrm{ka}$ ), Subunit 2 (E: $190 \mathrm{~cm}$, $13.5 \mathrm{ka}$ ), and Subunit 3 (A: $40 \mathrm{~cm}, 2.3 \mathrm{ka}$ ). Sample A displays higher coercivity behavior than samples E and H, consistent with a distinctive change in mineralogy. Raw data points were smoothed using a MATLABTM loess filter prior to IRM decomposition, as is indicated by the thick solid lines. 

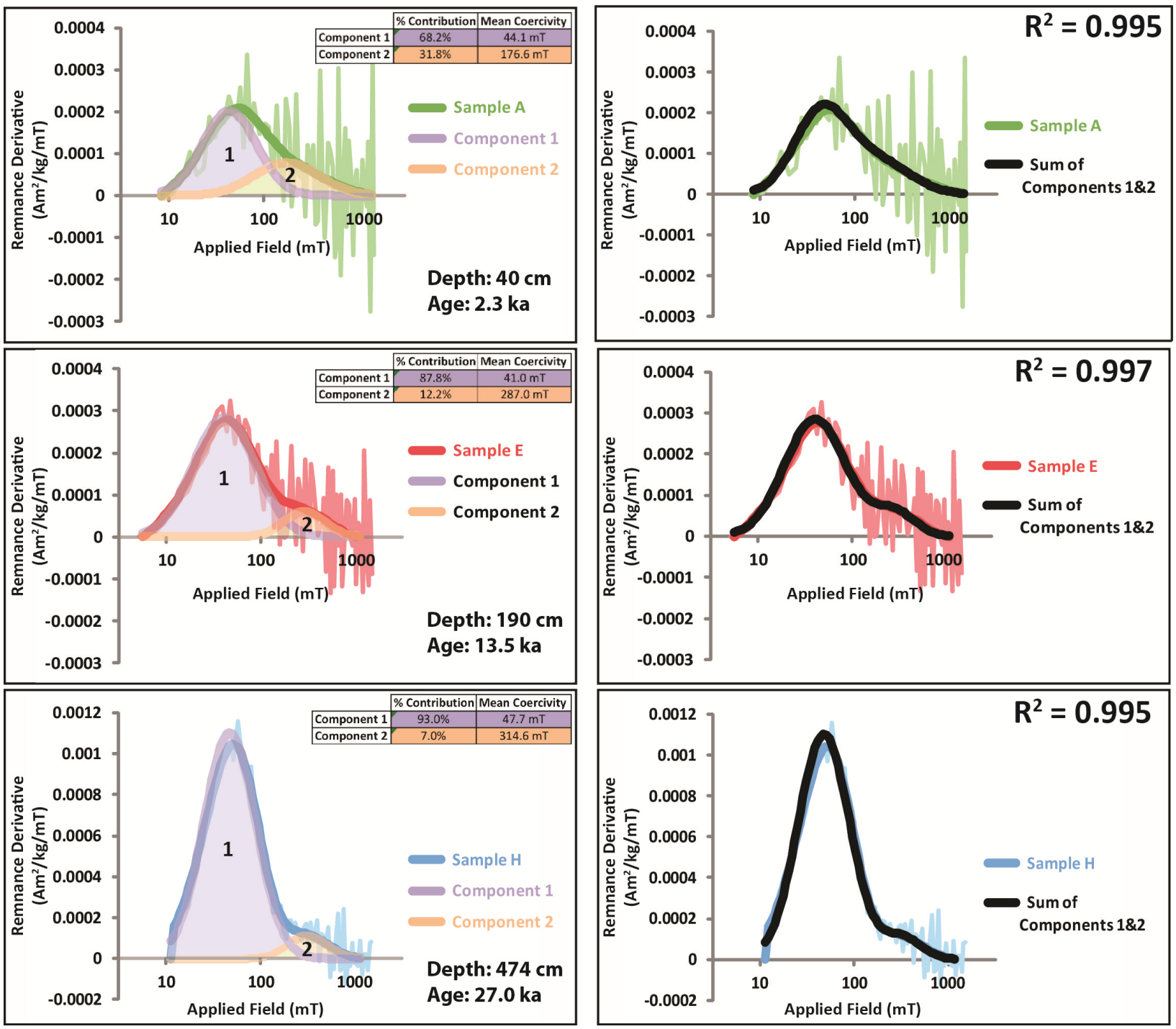

Figure 7.Left column:IRM decomposition results based on smoothed data from Figure 6. Non-normalized input data for representative samples from Subunit 1 (H: $474 \mathrm{~cm}, 27.0 \mathrm{ka}$ ), Subunit 2 (E: $190 \mathrm{~cm}, 13.5 \mathrm{ka}$ ), and Subunit 3 (A: $40 \mathrm{~cm}, 2.3$ ka) were analyzed using IRMUNMIX V2.2 (Heslop et al., 2002) to decompose curves into their individual component contributions. Raw data is shown behind the smoothed curve for each sample. Note applied field is plotted on a log scale. Burial Lake sediments are best described by a two-component model with both low coercivity and high coercivity sources present throughout the record. Component 1 (shaded purple) is characteristic of low coercivity minerals (magnetite), and its relative abundance decreases by $\sim 25 \%$ between Subunit 1 and Subunit 3. Component 2 (shaded orange) is characteristic of high coercivity minerals (hematite) and is ever-present throughout the record, but can easily be masked when component 1 is in high abundance (e.g., sample H in Subunit 1). Relative percent contribution and mean coercivity for each component is tabulated for each sample. Depths and ages for each sample are provided. Right column: The sum of components 1 and 2 compared against the smoothed input data, with $\mathrm{R}^{2}$ values given for each sample, demonstrating excellent correlation. Raw data is again shown for reference behind the smoothed curves. 
A.

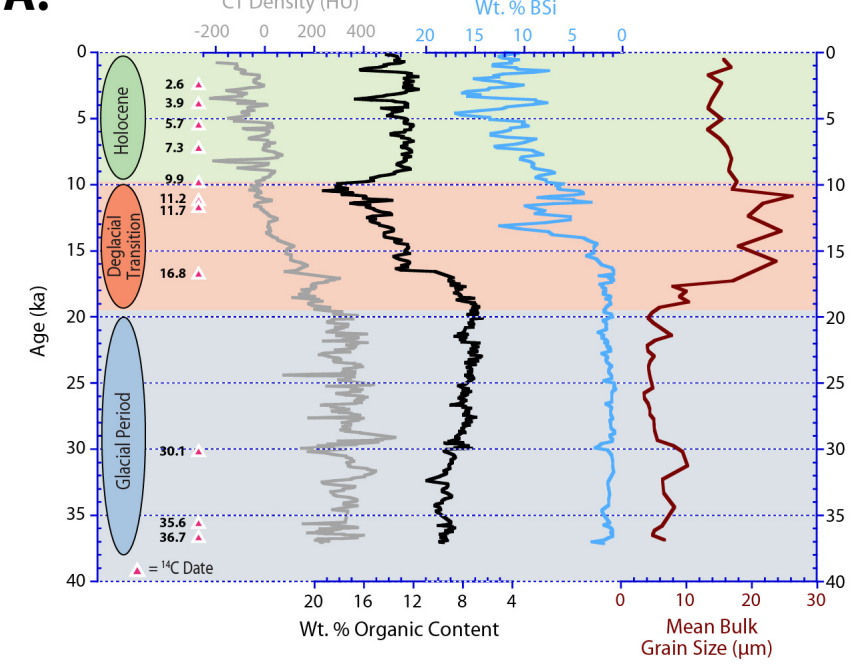

B.

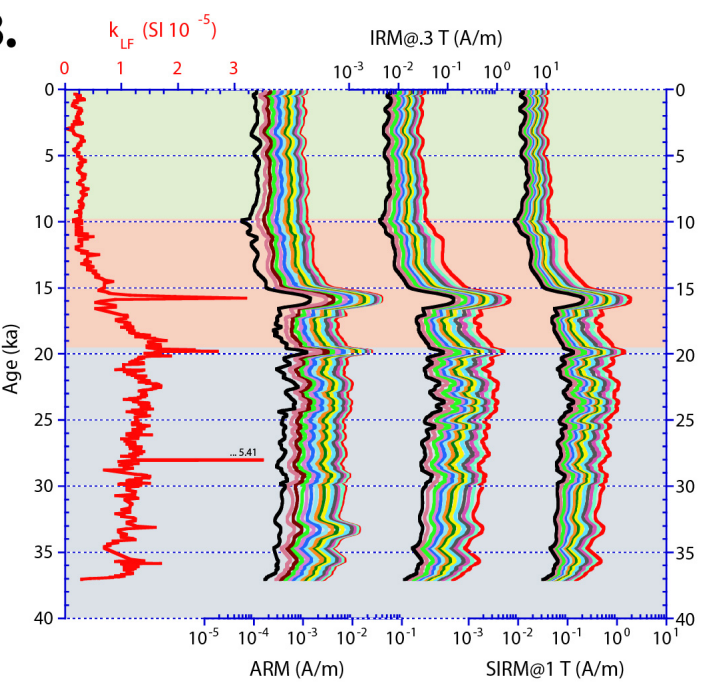

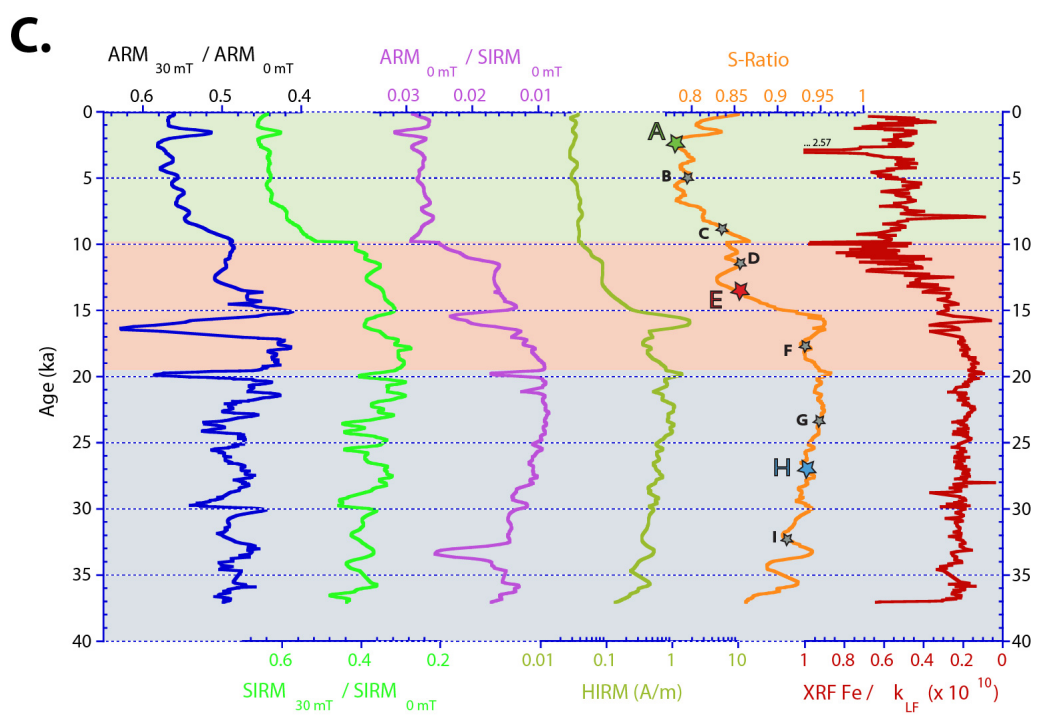

Figure 8.Down-core physical, geochemical, and magnetic properties versus age. A) Physical and geochemical properties: (from left to right) Radiocarbon ages (pink triangles) for reference, relative CT density, organic content, biogenic silica (BSi), and mean bulk physical grain size. Lithologic subunits are designated by color and are now labeled in terms of the time period they represent: The last glacial period (blue) from 37.2 - $19.4 \mathrm{ka}$, the deglacial transition (red) from $19.4-9.8$ $\mathrm{ka}$, and the Holocene (green) from $9.8 \mathrm{ka}$ to present. B) Concentration dependent magnetic parameters: Magnetic susceptibility $\left(k_{\mathrm{LF}}\right)$, anhysteretic remnant magnetization (ARM), isothermal remnant magnetization (IRM), and saturation isothermal remnant magnetization (SIRM), plotted with their respective alternating field (AF) demagnetization steps ranging from 10-80 mT.C) Magnetic ratios for coercivity/grain size/mineralogy: $\mathrm{ARM}_{30 \mathrm{mT}} / \mathrm{ARM}_{0 \mathrm{mT}}, \mathrm{SIRM}_{30 \mathrm{mT}} / \mathrm{SIRM}_{0 \mathrm{mT}}$, $\mathrm{ARM}_{0 \mathrm{mT}} / \mathrm{SIRM}_{0 \mathrm{mT}}$, hard isothermal remnant magnetization (HIRM), S-Ratios (stars and lettering indicate sample locations for IRM acquisition/decomposition, with enlarged colored symbols indicated representative samples from each subunit), and X-ray fluorescence (XRF) Fe/ $k_{\mathrm{LF}}$. Note some parameters are plotted on a log scale. 


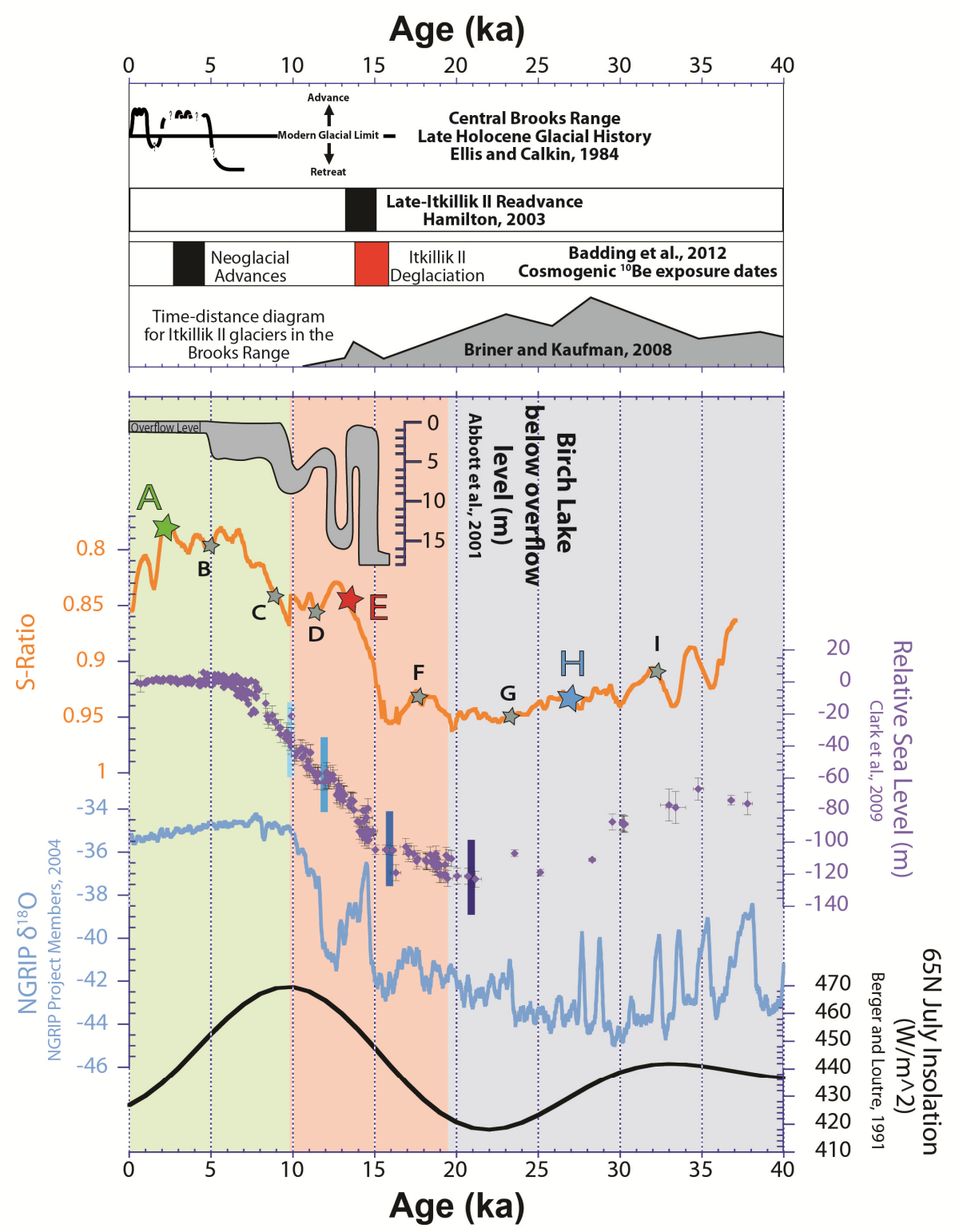

Figure 9. Comparison of Burial Lake S-Ratios with proxy data for regional paleoclimate, glacial history of the Brooks Range, and relative sea level shown on a calibrated age scale. Upper panel: (from top to bottom) Lichen-inferred late Holocene glacial history of the central Brooks Range (Ellis and Calkin, 1984), Timing of the late-Itkillik II readvance (Hamilton, 2003), Timing of ice-retreat (red bar) and Neoglacial advances (black bar) in the north-central Brooks range as delimited by cosmogenic ${ }^{10} \mathrm{Be}$ exposure dating (Badding et al., 2012), Time-distance diagram for Itkillik II glaciers in the Brooks range (Briner and Kaufman, 2008). Lower panel: (From top to bottom) Lake-level reconstruction for Birch Lake (Abbott et al., 2001), Burial Lake S-Ratios (stars and lettering indicate sample locations for IRM acquisition/decomposition, with enlarged colored symbols indicated representative samples from each subunit), Relative sea level (Clark et al., 2009), NGRIP $\delta^{18}$ O (NGRIP project members, 2004), Mid-month July solar insolation reconstructed for $65^{\circ} \mathrm{N}$ (Berger and Loutre, 1991). Colored vertical bars on the sea level curve correspond to the paleoshoreline bins shown in Figure 10. 


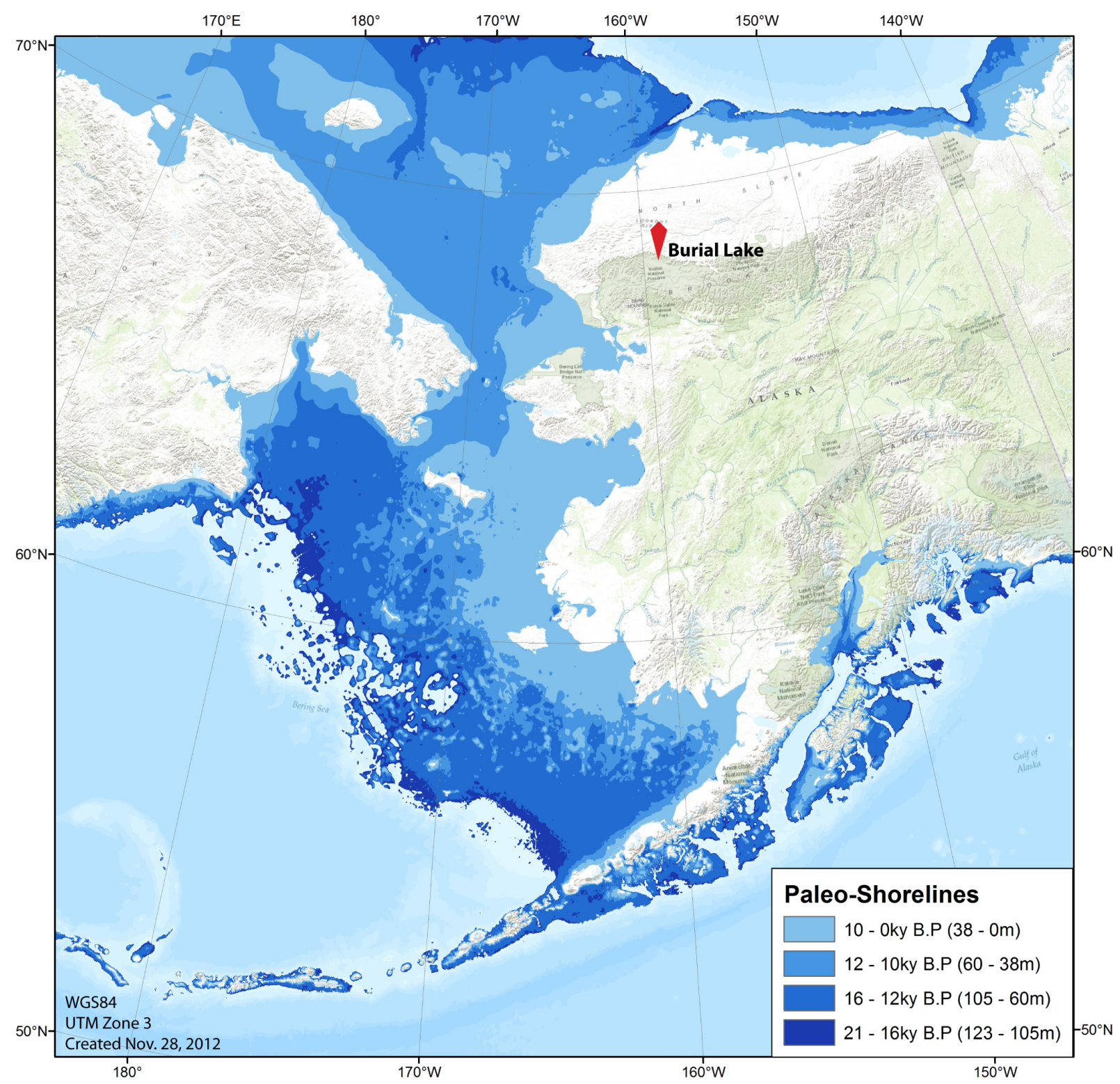

Figure 10.Paleo-shoreline map of Beringia showing sea level rise and inundation of Beringian continental shelves from the LGM sea level low-stand ( $\sim 21 \mathrm{ka})$ to present. Contours correspond to timing of major changes in S-Ratios at $\sim 16$, $\sim 12$, and $\sim 10$ ka (see Figure 9). 